\title{
The Role of E-Governance in Combating COVID-19 and Promoting Sustainable Development: A Comparative Study of China and Pakistan
}

\author{
Atta Ullah ${ }^{1}$ (D) Chen Pinglu ${ }^{2} \cdot$ Saif Ullah ${ }^{3}$ (D) Hafiz Syed Mohsin Abbas ${ }^{4}$ (D) \\ Saba Khan ${ }^{5}$
}

Received: 25 April 2020 / Accepted: 21 October 2020 / Published online: 6 November 2020 (c) Fudan University 2020

\begin{abstract}
This study's aim is to investigate the role of e-governance in combating COVID-19 by integrating the implications of the China-Pakistan Economic Corridor (CPEC). We discuss and analyze the E-Government Development Index (EGDI) reports and rankings issued by the United Nations and big data implications during the COVID-19 pandemic. We used the Origin-pro 2018 application for the analysis and discussion. Overall, China's EGDI ranking has improved from 74 to 65 out of 193 countries, while Pakistan's ranking has gradually declined from 137 to 148 . 5G and other big data technology and e-governance implications have helped to combat the COVID-19 pandemic. In this pandemic scenario, sustainable socioeconomic development in Pakistan needs significant improvement, similar to what has been done by China. We conclude that CPEC can help combat the COVID-19 pandemic because both countries are working together to mitigate social and economic problems. Pakistan should adapt and learn from the Government of China's experience of successful and proficient e-governance model of technological advancement. This effort will ensure successful CPEC regional extension and help combat the COVID19 pandemic to ensure Pakistan's sustainable development.
\end{abstract}

Keywords E-government · Big data technology $\cdot$ COVID-19 pandemic $\cdot$ Regional integration · China-Pakistan economic corridor · Sustainable development

JEL Classification $\mathrm{O} 19 \cdot \mathrm{H} 83 \cdot \mathrm{I} 28 \cdot \mathrm{B} 55 \cdot \mathrm{N} 35$

Atta Ullah

attaullah142@gmail.com

$\bowtie$ Chen Pinglu

cplcmhust@hust.edu.cn

Extended author information available on the last page of the article 


\section{Introduction}

In this advanced era, information technology (IT) should promote a knowledgebased society. E-governance stands for electronic governance; it is a unification of information and communication technology (ICT) in all the operations to augment the potential of the government to satisfy the requirements of the local public. E-governance is noteworthy because it minimizes corruption, enhances transparency, increases convenience, increases gross domestic product (GDP) growth, allows a way for citizens to be involved directly with their country, reduces overall costs, and broadens the spread of a government. Through an efficient e-governance system, the government increases the amount and quality of information and services delivered to the local public by using ICT in a simple, economical, and productive way. Earlier e-governance models have affirmed that e-government can promote economic growth. Of note, there is a difference between how developing and developed countries institute e-government. E-government has had a remarkably positive influence on the success and development of underdeveloped countries (Srivastava and Panigrahi 2016).

A large and well-known project, the China-Pakistan Economic Corridor (CPEC), can positively affect the entire region under the Government of China's Belt and Road Initiative (BRI). China and Pakistan would not be the only beneficiaries of this project; if used wisely, it can be helpful in numerous ways for many other countries in the region. By realizing CPEC's true potential, the Government of Pakistan can pinpoint those areas that indirectly or directly affect the socioeconomic plight of the people of Pakistan, such as the new Gwadar Master Plan. Therefore, the CPEC initiative would allow the Government of Pakistan to focus on areas such as technology and ICT development, establish the Gwadar Oil City and a blue economy, improve trade and market access, develop regional connectivity and third country participation, promote industrial development and global value chains, modernize agriculture and marketing, and ensure socioeconomic development to alleviate poverty. Yu and Chang (2018) expressed that problems vary from country to country and region to region, but they all have a common theme, which is to increase access to limited resources to improve livelihood.

Moreover, in the field of public health, the BRI offers immense opportunities to involve multiple countries for partnership and collective actions to globally fight the COVID-19 pandemic as well as other infectious or chronic diseases, and outbreaks of potential threats to both health information management (HIM) and laboratory information management (LIM) systems. Strengthening health systems is required for public health initiatives to extend beyond self-governing boundaries to affect worldwide geo-economics (Tambo et al. 2019). However, the regional effects of the COVID-19 pandemic on the BRI and sustainable development have not yet been explored.

The World Health Organization (WHO) declared the COVID-19 outbreak as the sixth public health of emergency of international concern on January 30, 2020. It started in Wuhan, China, and has since affected more than 209 countries (Waris et al. 2020). At the Munich Security Conference held on February 15, 
2020, the WHO Director-General Tedros Adhanom Ghebreyesus, said, "We are not just fighting an epidemic; we are fighting an infodemic." WHO launched a new information platform called the Information Network for Epidemics (EPIWIN) after declaring COVID-19, a public health emergency of international concern. The goal behind the new information platform was only to reveal customized information with concerned focus groups (Zaroncostas 2020). Finally, on March 11, 2020, WHO declared COVID-19 a global pandemic (Hua and Shaw 2020). COVID-19 quickly spread in less than 3 months. The strategies to slow the spread have been social distancing (physical distancing), 14-day quarantine, selfisolation, breaking the chain, mitigating community spreading, and lockdowns.

As of June 17, 2020, there is no vaccine available for COVID-19, but different countries have used medicines to treat this disease without proper regulatory approval. Therefore, the only way to stop spreading the virus is social distancing and self-isolation. This practice has required the potent combination of e-governance, innovative use of existing and advanced technologies, and strong community solidarity as well as citizen participation to combat the disease's long-term effects (Shaw et al. 2020). Government-run and public state-funded health systems have been strained and gradually dismantled in many countries. Coping with this global pandemic and, indeed, future global pandemics requires robust public, sustainable e-health systems (De Ceukelaire and Bodini 2020).

E-governance focuses on sustainable development goals (SDGs). Sustain means to support, endure, or maintain, and sustainable development is defined as a fluid activity directed at stabilizing the present and future challenging requirements such as the ongoing and future impacts of COVID-19. SDGs have developed from social, environmental, and economic fields to grab the attention of political, technological, and societal institutions throughout the world (Phimphanthavong 2014; Akber et al. 2017; Koirala and Pradhan 2020). Societal and environmental issues are the outcomes of economic actions. Consequently, the above-mentioned societal, health-related, cultural, environmental, and financial aspects must be combined in the economic analysis (Healy and Casey 2013; Hiss 2013; Kaimuri and Kosimbei 2017).

COVID-19 has affected human lives, the family atmosphere, and the pace of social and economic development, all of which have resulted in incalculable loss of sustainable development (Gao and Yu 2020). Still, there is no agreement about how ICT and e-governance/government can help unify cross-country differences (Faid et al. 2020). The COVID-19 pandemic has stressed every country's social, environmental, and economic indicators and has challenged how nations can continue their sustainability and development. Of relevance to this article, the relationship between e-governance and the COVID-19 pandemic has not been adequately explored with regard to CPEC. There needs to be a model to ensure sustainable development and benefits from CPEC. Sustainability proposes to fulfill present requirements while not harming future needs, which is critical to remember during emergency situations like the COVID-19 pandemic. Therefore, it is essential to study the role of e-governance in combating the COVID-19 pandemic to promote sustainable social and economic development by exploring insights from CPEC, which represents a road to successful regional integration. In addition, it would be useful to see how Pakistan 
can learn from China's development model to implement an efficient e-governance system to improve societal conditions.

The study research objectives are: to study the role of e-governance in combating the COVID-19 pandemic in CPEC; to compare China's and Pakistan's e-governance policies and evaluate how Pakistan can benefit from China's successful e-governance system; and to highlight the significance of e-governance to promote sustainable development in China and Pakistan during the COVID-19 pandemic. Therefore, this study addresses several research questions: How does e-governance play a role in combating COVID-19 in CPEC? What differentiates China e-governance policies with regard to CPEC from Pakistan and how can Pakistan learn and benefit from China's successful e-governance system in the view of CPEC and COVID-19? How can e-governance help build sustainable development in China and Pakistan vis-avis COVID-19 pandemic?

The study also comprises a brief review of the literature and policies regarding e-governance and combating COVID-19 in China and Pakistan. We then compare and discuss the situation in China and Pakistan, and we end with recommendations and policy implications.

\section{Literature Review}

\subsection{The Concept of E-Governance}

The concept of "governance comes equipped-explicitly or implicitly-with a qualifier that indicates that, whatever it is desirable and is a mechanism for managing common resources that can be applied to many goals such as sustainable, effective, sound, appropriate, honest, accountable, equitable, gender balanced and even democratic" (Schmitter 2019). The e-government is considered to be a pivotal tool for modernizing government in the twenty-first century. The e-government may be contemplated as technology by governance that should upgrade the work of current organizations and reorganize the network of interactivity between a government and its citizens and among businesses and employees. The e-government considers the "latest rules of the game" for this interactivity (United Nations [UN] E-Government Survey 2018). While e-government may be defined merely as an Internetbased instrument to deliver services for the public and enterprises, executing the e-government network requires a necessary conversion of manufacturing operations in the public sector (Solinthone and Rumyantseva 2016; Gustova 2017). There are four pathways that must be considered, as described below.

The government-to-citizen pathway furnishes citizens with the rights to search freely and transmit, produce, receive, and distribute information relevant to important issues such as state property management. These abilities increase the transparency of public authorities, monitoring citizen safety, budgetary process, and local governments.

The government-to-business pathway focuses on interactivity among the government and private sector in the fields of customs clearance documentation, taxation, issuing licenses and certificates, registration and liquidation of legal entities, and the 
preparation and submission of reporting documentation. The use of IT in this form of interaction is to enable an upgrade to supply chain management and to maximize the country's competitiveness in business endeavors.

The government-to-government pathway involves enhancing the capability of public authorities and local governments due to the utilization of an interdepartmental electronic information management system and the formation of new administrative practices. These actions, in turn, allow better coordination of public entities, cost reductions from an economic and social perspective.

Finally, the government-to-employee pathway supports transactions such as payroll and pension plans, the level of satisfaction of employees, and enhancing the advancement of the labor market, which can indirectly improve labor productivity via altering national standards. This advanced IT intends to restore the unrestricted formation of political communication and furnish it to a more enlightened and active citizenry (Yildiz 2007; Alshehri and Drew 2010; Albesher 2016; Stančić et al. 2017).

\subsection{E-Governance in China: Recent System, Policies, and Processes}

In 2001, the Government of China set a new goal that $80 \%$ of urban government agency facilities would be working online in 2005. Later that year, the National People's Congress approved the 10th Five-Year Plan (2001-2005), which set the goal of maximizing the number of Chinese Internet users to approximately 150 million by 2005 . That goal would undoubtedly have a significant effect on social requirements for Internet technology execution in commercial and public sectors that could improve the competency and productivity of government agencies. China's Internet economy is growing fast, which is an intravital driving force for the GDP and sustainable development. The Internet economy reached 8000 billion RMB in 2014. Since 2010, it has grown five to seven times faster than the GDP. China's Internet economy accounts for a higher proportion of its GDP compared with Germany, France, and the USA (Xu 2010).

WeChat, a mobile social networking application, is the most powerful app in China; it has a substantial group of users and its services are continually enlarged. In late 2014, public services were added to the WeChat platform. They provide extraordinary convenience to users in their daily life. Government e-services have been combined within the Weibo and WeChat principal platform functions from messaging to payment (Hou 2014). The Chinese model of government services-making use of social networking applications - is an effort to ensure its citizenry uses the services, while other nations may be worried about releasing personal data and outsourcing government services to private corporations (Yang 2017).

According to the 2018 UN study on e-government, "mobile" currently has the most positive Internet expansion. There is a massive expansion capacity. Moreover, China powerfully underpins the growth of mobile Internet groundwork. The China Internet Network Information Center recently reported that about 600 million people used online payments in 2018, a $13 \%$ increase over 2017. In addition, the push for e-government is driving the creation of an electronic China and dynamic growth. 
There are currently more than 570 million WeChat city service users. Furthermore, WeChat's 30,000 government mini-programs have assisted more than 900 million people in 362 cities across the country.

In the development of e-government, China has made significant advancement over the last two decades. In China, the Internet serves as another channel for citizens and officials to engage via expansion of government websites. For example, requests can be completed online without the need for paperwork. Furthermore, the Government of China has not just been cataloging information; rather, they have also provided higher efficiency for agents and customers via electronic transactions. A full-featured e-government will undoubtedly increase savings for the government and citizens and provide more efficient service delivery. As a revolutionary entity, the Chinese e-government endeavor has changed the way citizens interact with the government; they can approach the government at any time while saving time without having to wait in line for paperwork and the inconvenience of having to travel to physical government agency locations. Since 1999, e-government has grown quickly in China to provide information and services via websites. These processes cover all levels of the government. In 2015, e-government covered $99.1 \%$ at the city level, $100 \%$ at the national and provisional level, and more than $85 \%$ at the county level, with about 58,000 official websites. The local governments of China have been accelerating the usage of mobile apps to provide more convenient services to citizens. In addition, to promote policy-making and e-government development, big data has been utilized by various city governments ( $\mathrm{Lu} \mathrm{2018).}$

\subsection{E-Governance in Pakistan: Recent System, Policies, and Processes}

In 2002, behind a significant improvement in ICT, e-governance was first introduced in Pakistan. The Ministry of Science and Technology has developed the Electronic Government Directorate (EGD) for proper e-governance implementation. Under the EGD, the Government of Pakistan has taken a number of noteworthy steps, such as increasing speed/access to the Internet and the use of mobile phones nationwide. In Pakistan, the telecommunications sector has gone through several fluctuations in structure and regulation. Moreover, the introduction of next generation mobile services (NDMS), also recognized as 4G long-term evolution (LTE) services, has stimulated the digital revolution in Pakistan. To ensure future ICT development in the state, the Pakistan Telecommunication Authority launched the Smart Pakistan initiative (Ud-Din et al. 2017; Rafiq 2018). The latest survey by the Pakistan Telecommunication Authority (2019), completed in response to the Smart Pakistan initiative, showed 61 million 3G/4G subscribers and 63 million broadband users, from a total population of 220 million people at the end of December 2018.

Many projects have been developed and completed in a more comprehensive way (Government of Pakistan Portal) by both the Ministry of Information Technology and the EGD. These projects include online services such as tracking the status of Hajj applications, the national assembly of Pakistan, e-enablement of the senate, and automation of the Prime Minister Secretariat. All provincial government departments have websites with their respective province name, which are collated 
on a Web portal to help citizens. Moreover, e-services have expanded toward salary disbursement through ATMs, mobile services (PTA SIM verification and NIC verification), passport and visa services, and document submission at the Securities and Exchange Commission of Pakistan. Likewise, in the Department of Education, National Testing Service, Higher Secondary School Certificate, and Secondary School Certificate, citizens can view the results for all boards online. There are also an online Urdu dictionary, tourism guides, and many more services (Butt et al. 2019).

Internet usage in Pakistan has increased year by year, a phenomenon that shows the country has a technologically friendly environment. Pakistan is considered to be a developing country, but people want e-services from the government to ease their life and, ultimately, promote sustainable development of the country (Rehman et al. 2018). The Pakistan Citizen's Portal was inaugurated by Pakistan's Prime Minister in October 2018 to allow citizens to submit complaints and suggestions using digital platforms. A total of 250,000 of 420,000 complaints submitted through the portal had been resolved as of February 2019, with 55\% satisfactory feedback from citizens. In November 2018, a 5-year plan approved by Pakistan's Prime Minister focused on increasing contact to digital transaction accounts and promoting digital payments, which upgraded the National Financial Inclusion Strategy. At the national and provincial levels, there have been digital health initiatives the National Database and Registration Authority (NADRA) e-Health cards, and the Government of Punjab and Khyber Pakhtunkhwa rolled out a vaccination project (e-Vaccs) in collaboration with WHO and Pakistan's Federal Ministry of Health (Okeleke 2019).

Fighting the COVID-19 outbreak has required strict social distancing. Hence, Pakistan has been forced to go digital due to the COVID-19 pandemic. The government developed the Geo-Tracking App to facilitate consultation with telecommunication companies. Once a person has been identified as infected, a message will be delivered to their nearby authority for awareness and safety purposes. Some online services provided in this situation include the TeleMedicine Center at Nishtar Medical University situated in Multan. A specific app/webpage can be launched and serve as the official portal for self-assessment. In addition, electronic consultancy services are provided to regular patients who are not infected. This electronic participation precludes patient intake in outpatient departments for treatment, an endeavor that will effectively mitigate the possibility of contracting COVID-19. The Ministry of Education signed an agreement with PTV (Pakistan Television) to develop Tele School. Moreover, the Government of Pakistan has launched a WhatsApp helpline for the COVID-19 pandemic (Haque and Nayab 2020).

\subsection{Worldwide E-Government and the COVID-19 Pandemic}

E-government is an interconnected system in which the government interacts with citizens and provides augmented services to them through electronic applications. With the assistance of ICT, e-governance has been implemented, and digitalization opportunities in the world are being revolutionized (Khan et al. 2020). E-governance furnishes a rare possibility for governments to increase electronic identity record 
keeping and expand the ability to share social and economic results. Based on surveys, 80 out of 100 republics made available particular actions to certify e-government e-services utilized by the highly sensitive portions of their populace in 2018 , which was a marked increase from $<30 \%$ in 2012 . There is immense importance for mobile-government facilities to provide social services such as distance education and health, which would have a positive effect on an individual's daily life. These services are particularly important for rural populations, because they tend to live in poorer condition compared with urban populations (Sarker et al. 2018; UN 2018).

Worldwide, there are currently an estimated 1.1 billion individuals who are surviving in neediness, are refugees or migrants, are living in agrarian societies, or are part of other ignoble clusters without a legitimate identity. Therefore, several SDGs-SDG 16 refers to peace, justice, and strong institutions and SDG 16.9 refers to providing a legal identity to all individuals, including birth registration-seek to ameliorate these issues by 2030. Growing financial institutions and avoiding corruption and fraud can serve to improve the economic situation of individuals, while providing social services can help furnish legal identities to these ignoble clusters. Together with the full advantages of connectivity, the quality and speed of mobile connections must also be augmented. Moreover, the rapid increase in cell phone acceptance in developing markets is furnishing support in ameliorating the connectivity divide.

To gain advantages by shifting higher volumes of information to cell phone systems, the speed and network quality must be improved. Approximately, $85 \%$ of the global populace currently uses the $3 \mathrm{G}$ network, which is the minimal speed required for smart data functions. Moreover, the upcoming network generation, i.e., 4G cell phone wideband contributions, are lagging behind. The growing variety of government facilities that are furnished online makes digital divides more apparent. Digital divides refer to the gap between demographics and regions that have access to modern ICT and those that do not or have restricted access. This technology can include telephones, televisions, personal computers, and the Internet (Otioma et al. 2019). Governments may unintentionally generate fresh electronic divides by eliminating off-line access for services that can utilize online methods, an action that encourages the digital-first method. Therefore, online services are being favored as countries move forward to accept a more electronic government to promote quality and availability. For the expansion of digital usage, some countries are producing "digital by default" facilities, which mainly to utilize online services and provide few off-line facilities. Denmark has adopted a "digital first" method: electronic communication has become compulsory, although they also provide off-line help to those who are incapable of finishing services online. In a similar manner, digital assistance initiatives have also been established by the UK to examine advancement; the government is utilizing a work tracking instrument panel for facility managers, which allows them to trace facility consumption on electronic and non-electronic networks (Andersen et al. 2019).

Broad digital skills can support social inclusion and help to respond to an emergency, so digital literacy is especially important. Hence, children in schools should be trained with these skills and their use should be improved among civil employers/employees in the public and private sectors. Moreover, an electronic 
assistance starter course would be useful to help citizens who are unskilled in using online services. In Singapore, the government developed the Silver Infocomm Initiative (SII) to link the connectivity divide for older individuals by ameliorating their deficiency in electronic skills and education. The SII aims to bridge the digital divide among seniors aged $\geq 50$ years. This important initiative has allowed Singapore to evolve into a digital economy and a cohesive digital society. It has promoted IT awareness and literacy among seniors to empower them to be digitally ready in a digital society. Furthermore, reaping the e-government benefits is vital to improving digital skills among the public sector employees, which has been noted by the European Union Commission (Ali et al. 2018; Dresel et al. 2020).

Ma (2019) found that online payment systems are more efficient, fast, convenient, and economical than a traditional payment system. The entire payment process can be done by using mobile phones and the Internet in a short amount of time. Through PayPal, individuals and businesses can more efficiently, conveniently, and securely allocate money online with email addresses. To create a simultaneous payment solution, the network only requires a bank account and credit card. PayPal is the most popular online payment system around the world; it deals with 26 currencies from 193 markets. There are 137 million PayPal accounts, and every day there are 8 million transactions. During the COVID-19 lockdown and other restrictions, PayPal users have been able to make payments while quarantined in their houses when the banks were closed. For many people, the only option was to make payments through the PayPal app because PayPal provides payment solutions around the globe. Of note, PayPal does not operate in Pakistan. In China, people make payments through WeChat and AliPay, while most people from other countries choose the local banking system and PayPal to make payments.

Health-care providers are at high risk for contacting COVID-19 (Wang et al. 2020). Alwashmi (2020) expressed that for COVID-19, free triage telehealth assessment has been offered by health institutions of many countries. Telehealth assessments are provided to patients by a mobile app or website that contains a short survey about the patient's current condition. Moreover, this survey contains questions about the patient's age, travel history, and symptoms. The results determine the next step: the patient may be asked to connect with the digital health-care provider or visit a mobile testing site/hospital for COVID-19.

Buoy Health (2020a, b) and Lark Health (2020a, b) are websites with healthfocused chatbots and can also provide help to interpret an individual's symptoms and propose the appropriate next step. Furthermore, to assure continuity of care, the survey results are integrated with electronic medical records. In Singapore, the "Trace Together" mobile app is currently used to assist in COVID-19 contact tracing. This app uses Bluetooth technology to determine whether the person has had any close contact with a COVID-19-diagnosed patient name as GOVTECH Singapore, 2020. Aiva Health (2020a, b) and Deloitte Assistant (2020) have provided artificial intelligence systems that offer information and help to patients without smart assistants such as Google Home and Amazon Alexa. These interventions enable health-care providers to respond to any patient's needs without entering their rooms and reduce their exposure to respiratory secretions and, ultimately, disease transmission. 
A rapid diagnostic "drive-through screening" kit developed in Korea has the potential to diagnose COVID-19-infected people in the early stage of the disease. This eventuality reduces the fatality rate and prevents transmission, an innovative method that allows thousands of people to be tested daily. The new diagnostic kit reduced test time from 24 to $6 \mathrm{~h}$ by employing the real-time reverse transcription polymerase chain reaction and was rapidly approved by Korea Centers for Disease Control and Prevention (KCDC) and Ministry of Food and Drug Safety (MFDG). A kit is usually approved within 1 year from development, but both KCDC and the MFDG approved it within a month, allowing it to be quickly applied in the field. This method was first implemented on March 16 in the Yangji Hospital in Seoul. The open walk-through booth was installed by the Government of Korea at Incheon Airport on March 25 to deal with foreigners. The KCDC developed a self-diagnosis mobile app to strengthen monitoring by letting foreign and domestic travelers enter Korea to self-diagnose health condition regarding COVID-19 and report the results to the KCDC or their local health center. If the user entered the information regarding quarantine such as name, nationality, and passport information, then the KCDC was able to monitor them throughout their stay in Korea. In addition, the Ministry of Interior and Safety (MoIS 2020) developed a self-quarantine safety protection mobile app to decrease the administrative costs borne by public administration to monitor self-isolators for local government (Shaw et al. 2020).

During the COVID-19 pandemic, the implementation of digital health has aimed to reduce the risk or avoid the transmission to medical service providers. The abovementioned technology applications have the potential to reduce transmission risk by abating physical contact among patients and health-care providers. Moreover, digital health involvement enables medical service providers to tackle the global pandemic even when working remotely or practicing self-isolation measures.

\subsection{The Significance of Regional Integration Through CPEC}

There has been a growing integration of national economies throughout the world. China's BRI budget is estimated to exceed 1 trillion USD and involves more than 65 countries. The goal is to link China across Asia, Europe, the Middle East, and Africa. This linkage has direct and indirect global developmental impacts that can be separated into four categories: (1) information harnessing, technology, and health; (2) easier commerce and trade; (3) augmented energy resource safety; and (4) the drive toward global health-driven development (Tambo et al. 2019). CPEC is part of the BRI. It provides China with a competitive alternative to the Strait of Malacca sea route by significantly reducing shipping time from 45 days to only 10 days and serves as a game changer to boost Pakistan's social, technological, industrial, and trade developments (Haider 2015; Zaidi 2016). CPEC may link China with the Indian subcontinent, Central Asia, and Africa; this linkage is geographically important because it could benefit about 3 billion people in this prominent region. CPEC short-term goals have up to a 5-year time frame, while long-term goals will take 10-15 years to be completed (Hussain 2017). CPEC entails a Chinese investment package of 46 
billion USD, comprising an array of infrastructure projects, including railways and highways initiatives that connect Gwadar (Balochistan) and Kashgar (Xinjiang) to other Islamic countries, Asia, and Europe (Wang and Selina 2018).

Pakistan's economy has improved after CPEC integration (Mangi and Haider 2014). The CPEC venture can indirectly or directly provide an easy entry to main comforts or conveniences of life such as markets, education, health, banking, transportation, and participation toward the betterment of Pakistani living standards, and lead to growth and success (Haider and Haider 2015). The Government of Pakistan announced a special package where there will be tax- and duty-free import of machinery for special economic zones for 10 years (Mazher et al. 2015). CPEC is a prominent value-added project and directly connects China and Pakistan (Ali and Qazi 2018). Its primary purpose is to enhance trading activities between China, Pakistan, the Middle East, Africa, and Central Asia (Farooqui and Aftab 2018). Sustainable development goals have become the primary objective; therefore, CPEC includes regional interconnectivity, construction of infrastructure, technology advancement, economic zone establishment, agriculture improvement, energy production, and, especially, poverty reduction through education, livelihood improvement, and better public health facilities (Menhas et al. 2019).

CPEC includes a wide variety of projects in the field of industry, services, technology, and agriculture. This initiative can allow emerging markets to upgrade trade, improve markets, add value, and provide entrepreneurship and competitiveness among CPEC trading allies. Trade tactics, productive discussions, and policy advances with member nations can improve Pakistan's overall trade and entrance into new markets. For example, mobile telephony has brought new possibilities to African countries. Across urban-rural and rich-poor divides, mobile phones connect individuals to other individuals, information, markets, and services. These effects can be particularly dramatic in rural Africa because in many places, mobile phones have represented the first modern telecommunications infrastructure of any kind. Mobile phones have significantly reduced communication costs, thereby allowing individuals and firms to send and obtain information quickly and cheaply on a variety of economic, social, and political topics. In this current scenario, it has also helped to combat COVID-19. Countries are now working on big data networks, applications, and software to collect and disseminate useful and relevant data. Big data is a new concept, and the world is currently focusing on this concept. China has an excellent recordkeeping capability compared with Pakistan. China also has more profound and relevant knowledge related to African countries compared with Pakistan. Therefore, CPEC can provide an entrance to developing economic endeavors and a many examples of success. Under CPEC projects, China and Pakistan are working together to seek out social and economic problems and gain benefits from technological advancement; hence, e-governance is a relevant part of CPEC. In addition, Sun (2019) claimed that the opportunities and constraints provided by the political regimes shape governance values, which further influence governance practices in neighboring countries. 


\section{Data and Methods}

We used data about sustainable indicators-from 2003 to 2020, based on availability - as well as COVID-19 indicators from the beginning of the pandemic to June 18, 2020, to compare e-government in China and Pakistan. COVID-19 data included the number of total patients, number of total deaths, number of daily confirmed cases, and number of daily deaths up to June 18, 2020, updated by WHO. Technology and e-governance usage and enhancement during the COVID19 pandemic can also be predicted from a country's overall Internet performance. Therefore, we also tracked the impact of COVID-19 on China's and Pakistan's Internet performance from December 2019 to June 15, 2020 (data obtained from Ookla 2020).

We collected several e-government survey indicators-E-Government Development Index (EDGI) ranking, which includes the Human Capital Index (HCI), Online Service Index (OSI), and Telecommunication Infrastructure Index (TII), and the E-Participation Index (EPI) - from the UN e-government database. The EGDI is based on a wide-ranging investigation of the 193 UN member states that have an online existence. It evaluates their e-government plans, strategies, national websites, and how they are working in specific and common sectors to provide essential services. This index measures how countries' e-government work relative to one another as opposed to being a perfect measurement ranked by evaluation. The results are shown in tabular form along with the set of indicators, which represent the state's potential for contribution in a data society. However, the fundamental model has stayed constant, while the meaning of the values has differed from one survey to the next based on e-government fluctuations capacity and underlying technological development. There are three noteworthy components of e-government: the OSI, the HCI, and the TII. The EGDI is a weighted average of normalized scores of the three components:

EGDI $=1 / 3$ (OSI normalized + TII normalized + HCI normalized $)$.

Z-score standardization is executed for each component indicator to ensure that each component index shows equal variance. The EGDI would show considerable dispersion due to the component indices if $\mathrm{z}$-score standardization was not executed. The arithmetic average sum is a suitable statistical indicator after z-score standardization, where "equal weight" truly means "equal importance." For standard z-score calculation of each component indicator:

$\mathrm{Xnew}=(\mathrm{x}-\mu) / \sigma$, where $\mathrm{X}$ is a raw score to be standardized, $\mu$ is the mean of the population, and $\sigma$ is the standard deviation of the community.

Socioeconomic development indicators are the Human Development Index (HDI), real GDP growth, the Globalization Index, and ICT exports, all of which can be obtained from the World Bank (2015) development indicators database (available up to 2018). Real GDP growth is the rate of change in annual economic growth. The HDI ranges from zero to one point and measures human development report (2018) basic three dimensions, i.e., health and long life, a decent standard of living, and knowledge. Four indicators are calculated for the HDI: birth life expectancy rate, expected schooling years, mean years of schooling, and gross 
national income per capita. HDI data is obtained from DataStream. The Globalization Index is based on social, economic, and political dimensions. It is from the Swiss Institute of Technology in Zurich and ranges from 0 to 100; higher values denote greater globalization. Data is obtained from DataStream.

The Social Globalization Index (0-100 points) is based on information flow, personal contacts, and cultural proximity. The sub-index on personal contacts includes international telecom traffic, the degree of tourism, transfers, foreign population, and the number of international letters. The sub-index on information flow includes the number of Internet users, the household share with a television set, and trade in newspapers. The sub-index on cultural proximity includes trade in books and several McDonald's restaurants and Ikea located in a country. The Globalization sub-index of political system is based on 0-100 points of China and Pakistan. The Economic Globalization Index (0-100 points) has two dimensions. The first is actual economic flow (sub-indices include data on trade, portfolio investment, and FDI). The second dimension included restrictions to trade and capital (including sub-indices on restrictions that consider hidden import barriers, mean tariff rates, taxes on international trade as a share of current revenue, and an index of capital controls).

We analyzed the nexus between the COVID-19 pandemic and e-governance using Origin-pro 9.5.1-2018 software. Origin-pro features include fitting comparison, curve fitting, dataset comparison tools, and multi-dimensional data analysis. Origin is a powerful and full-featured data analysis software and supports Unicode characters, which enable users to select from a wide array of characters that can be used in worksheets, legends, and other fields. Origin-pro statistical functions, batch data processing, and fitting functions are generally intuitive, the quality, diversity, and ease of plotting publication-quality figures in Origin matches or surpasses other data analysis and graphing software packages (Moberly et al. 2018).

\section{Analysis and Discussion}

\subsection{Statistics of COVID-19 Cases in China and Pakistan}

Tables 1 and 2 show the descriptive statistics about COVID-19 cases in China and Pakistan from the date of the first COVID-19 patient to June 18, 2020. There were 150 observation days for China (Table 1) and 113 observation days for Pakistan (Table 2). The mean and median values describe the measure of central tendency, while skewness can explain any lack of symmetry, i.e., concerning the central point, whether the left and right sides of the curve are unequal. Standard deviation indicates the extent of deviation for a group as a whole, and kurtosis indicates the degree of tailedness in the frequency distribution. The coefficient of variation is the ratio of the standard deviation to the mean value; it is presented as a percentage, and a higher value indicates a greater level of dispersion around the mean.

Figures 1, 2, 3, 4 present comparisons between COVID-19 patients in China and Pakistan since the first confirmed case. Figure 1 demonstrates the total COVID-19 cases by date in China and Pakistan. As of June 18, 2020, the total number of cases in Pakistan are double compared with China. In February, there was a peak period in 
Table 1 Descriptive statistics of China COVID-19 patients

\begin{tabular}{lllll}
\hline No. of patients: & Confirmed: to date & Death: to date & Confirmed: new & Death: new \\
\hline Country & China & China & China & China \\
Patients Total sum & 84,903 & 4645 & - & - \\
Mean & 71951.07 & 3267.32 & 482.43 & 32.17 \\
Variance & 612799834.64 & 2285148.02 & 940615.08 & 12542.64 \\
Standard deviation & 24754.79 & 1511.67 & 969.85 & 111.99 \\
Skewness & -2.05 & -0.90 & 2.43 & 9.86 \\
Kurtosis & 2.66 & -0.33 & 5.46 & 109.85 \\
Coefficient variation & 0.34 & 0.46 & 2.01 & 3.48 \\
Min & 278.00 & 6.00 & 0.00 & 0.00 \\
Max & 84903.00 & 4645.00 & 5093.00 & 1290.00 \\
Median & 82902.50 & 3336.50 & 53.50 & 3.50 \\
No. of Obs & 150.00 & 150.00 & 150.00 & 148.00 \\
Unit & Person & Person & Person & Person \\
First Obs. Date & $1 / 20 / 2020$ & $1 / 20 / 2020$ & $1 / 20 / 2020$ & $1 / 23 / 2020$ \\
Last Obs. Date & $6 / 18 / 2020$ & $6 / 18 / 2020$ & $6 / 18 / 2020$ & $6 / 18 / 2020$ \\
\hline
\end{tabular}

Source: World Health Organization, Obtain from ceicdata.com

Table 2 Descriptive statistics of Pakistan COVID-19 patients

\begin{tabular}{lllll}
\hline No of patients: & Confirmed: to date & Death: to date & Confirmed: new & Death: new \\
\hline Region & Pakistan & Pakistan & Pakistan & Pakistan \\
Patients Total sum & 160118 & 3093 & - & - \\
Mean & 31199.62 & 633.75 & 1418.16 & 27.37 \\
Variance & $1751222,888.33$ & 684320.26 & $3197,344.37$ & 1073.91 \\
Standard deviation & 41847.62 & 827.24 & 1788.11 & 32.77 \\
Skewness & 1.53 & 1.38 & 1.49 & 1.37 \\
Kurtosis & 1.45 & 0.90 & 1.23 & 1.06 \\
Coefficient variation & 1.34 & 1.31 & 1.26 & 1.20 \\
Min & 2.00 & 0.00 & 0.00 & 0.00 \\
Max & 160118.00 & 3093.00 & 6884.00 & 136.00 \\
Median & 10513.00 & 224.00 & 605.00 & 16.00 \\
No. of Obs & 113.00 & 113.00 & 113.00 & 113.00 \\
Unit & Person & Person & Person & Person \\
First Obs. Date & $2 / 27 / 2020$ & $2 / 27 / 2020$ & $2 / 27 / 2020$ & $2 / 27 / 2020$ \\
Last Obs. Date & $6 / 18 / 2020$ & $6 / 18 / 2020$ & $6 / 18 / 2020$ & $6 / 18 / 2020$ \\
\hline
\end{tabular}

Source: World Health Organization, obtained from ceicdata.com

China, followed by a gradual increase in cases. However, by May and June the curve had flattened, which indicates that China had successfully mitigated the pandemic. In Pakistan, the first cases were confirmed on February 27, 2020, but from the beginning of April, when the government implemented a strict lockdown, there was 


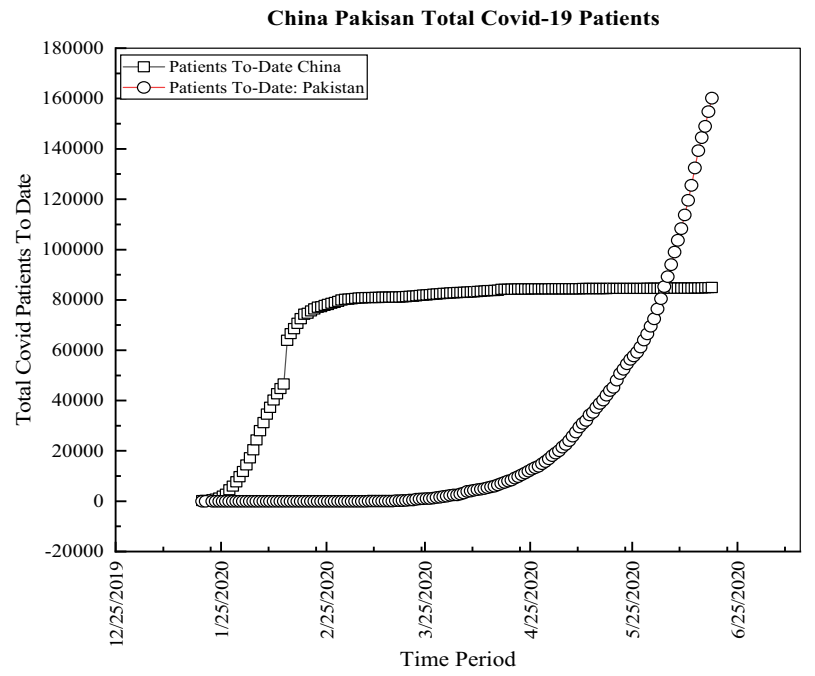

Fig. 1 Total number of COVID-19 patients in China and Pakistan. Our calculations are based on World Health Organization data obtained from ceicdata.com

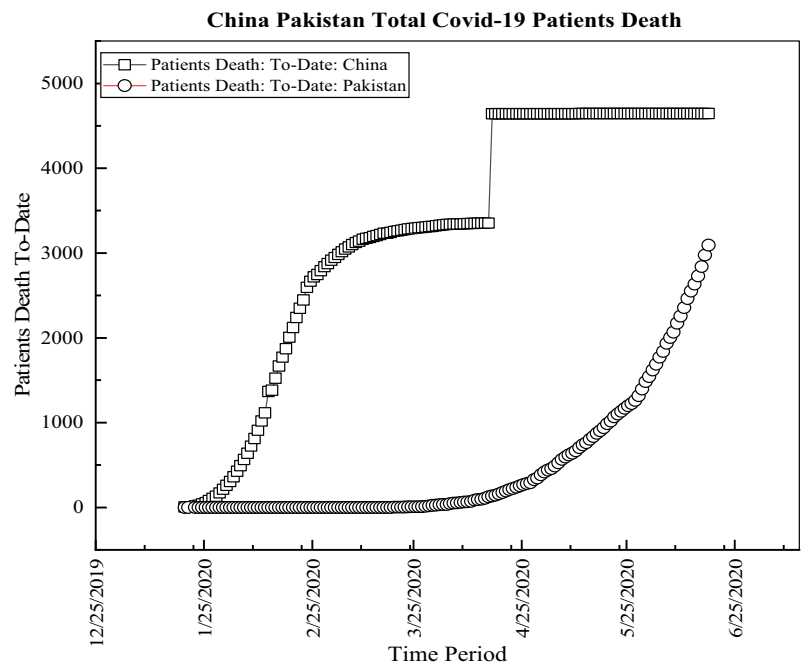

Fig. 2 Total number of COVID-19 patient deaths in China and Pakistan. Our calculations are based on World Health Organization data obtained from ceicdata.com

a peak in cases. Pakistan is still currently affected by the pandemic as the number of cases increases each day. Figure 2 shows the death trend of COVID-19 patients from China and Pakistan. Figure 3 shows the number of new daily confirmed cases, which indicates that China reported new cases until the end of April, after which there were almost no new cases. In Pakistan, new confirmed cases increased from the end of April, and there have continued to be a marked number of new patients, 


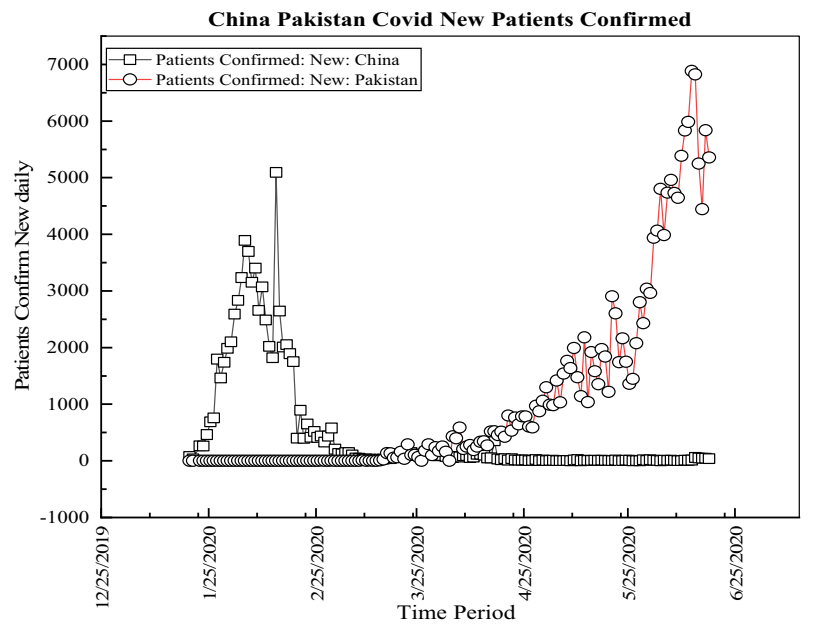

Fig. 3 Number of new confirmed COVID-19 cases per day in China and Pakistan. Our calculations are based on World Health Organization data obtained from ceicdata.com

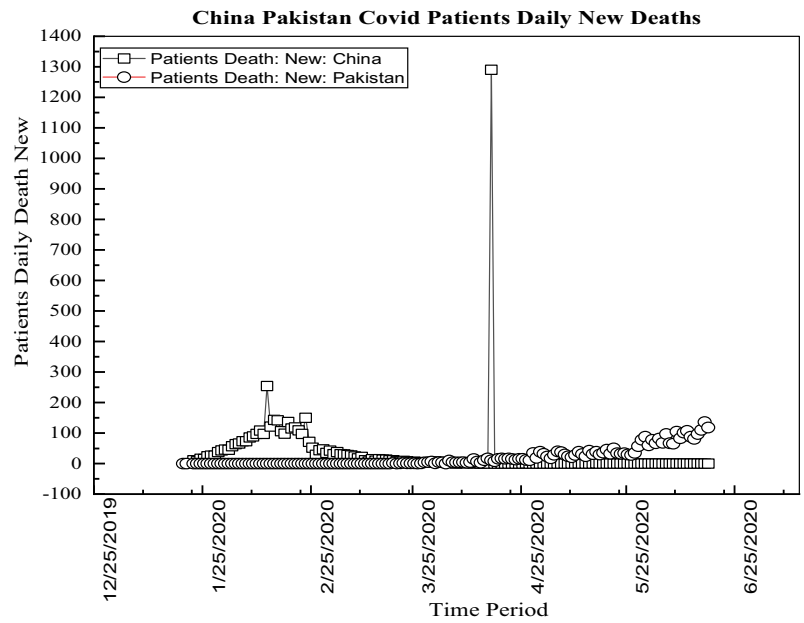

Fig. 4 Number of daily new COVID-19 deaths per day in China and Pakistan. Our calculations are based on World Health Organization data obtained from ceicdata.com

which confirms that the situation in Pakistan is getting worse. Figure 4 demonstrates the number of daily new deaths, which shows that the patient death ratio is stable in China, while in Pakistan the death ratio is increasing.

\subsection{Comparison and Discussion of Statistics}

The COVID-19 impact on China and Pakistan Internet performance (2020) is shown in Figs. 5 and 6, respectively. In China, the mean download speed over mobile and 


\section{China Internet Performance}

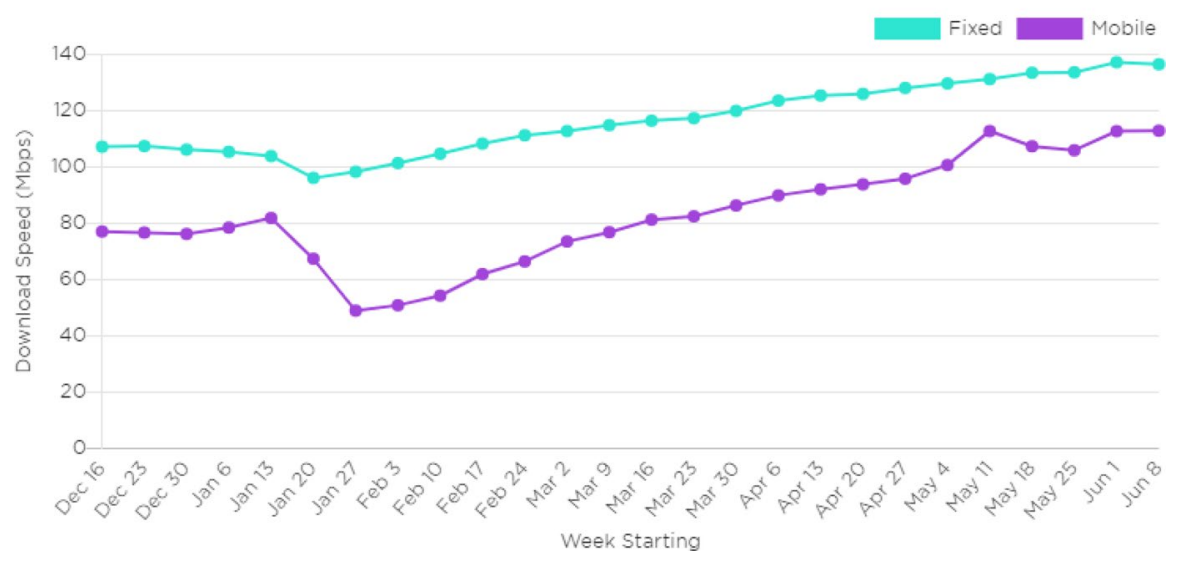

Fig. 5 China Internet performance during the COVID pandemic, December 2019 to June 15, 2020. Source: Speedtest, Ookla

\section{Pakistan Internet Performance}

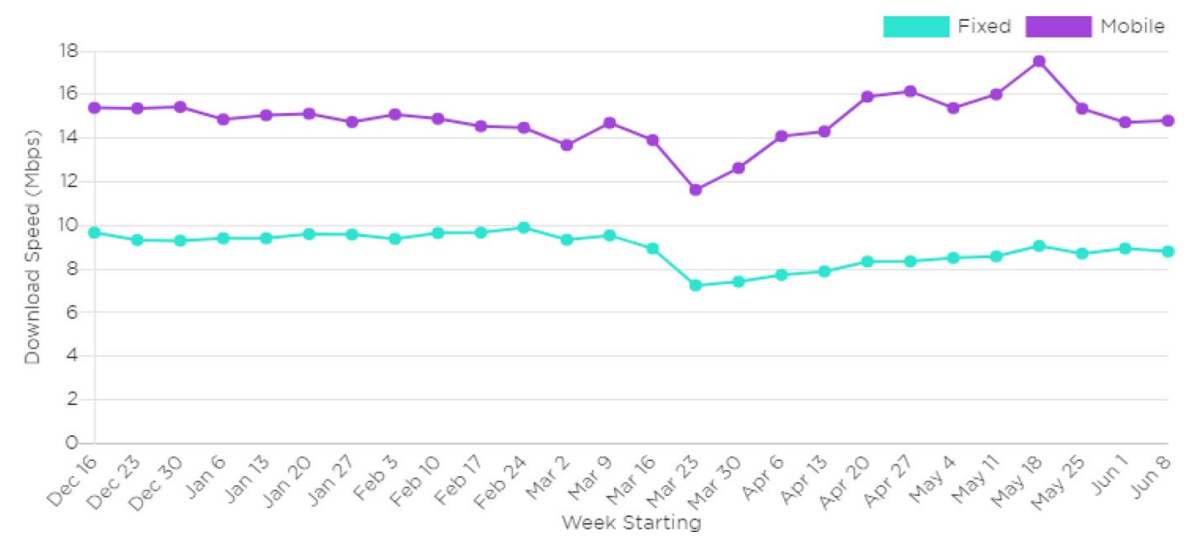

Fig. 6 Pakistan Internet performance during the COVID-19 pandemic, December 2019 to June 15, 2020. Source: Speedtest, Ookla

fixed broadband increased in December, decreased in January, and increased from February to May of note, in June both mobile and fixed broadband performances were relatively flat in China (Fig. 5). In Pakistan, the mean fixed broadband download was flat from December to February, decreased in March, and increased in April and May (Fig. 6). The mean mobile broadband speed in Pakistan decreased near the end of May, while the fixed download speed remained flat during the same period.

When comparing the e-government ranking between China and Pakistan, China is much better and improved from 2003 to 2018 (Fig. 7). In 2005, China's 


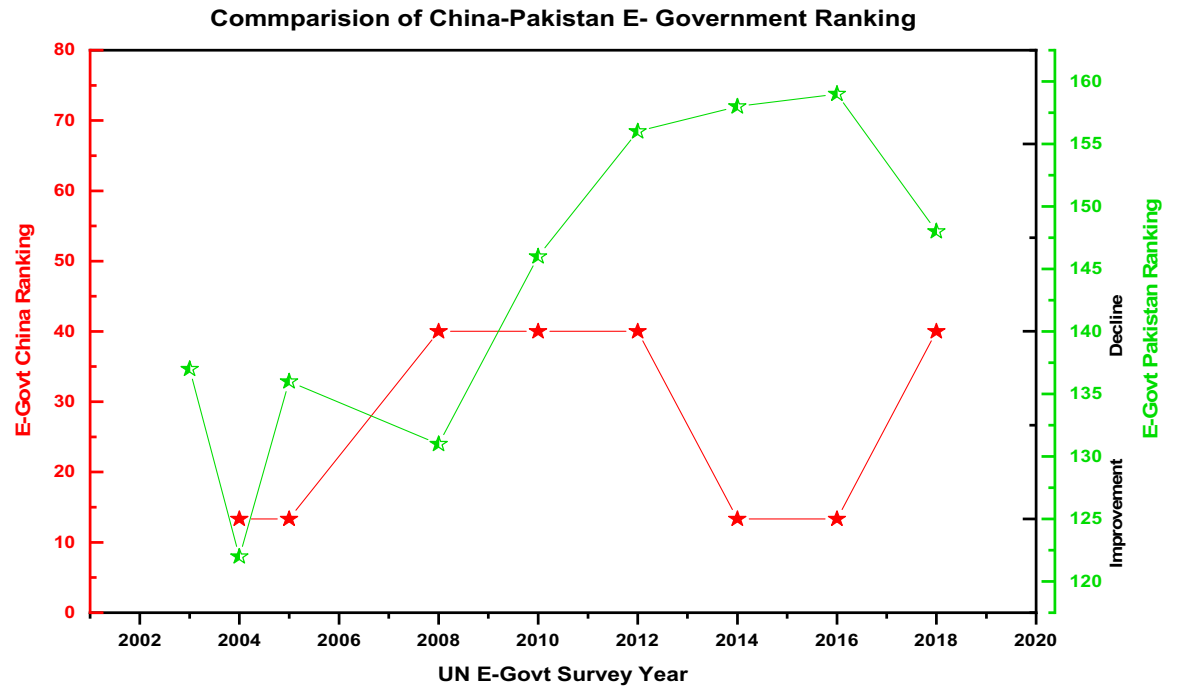

Fig. 7 E-government comparison between China and Pakistan (data source: UN.org)

e-government ranking improved to 57, from 67 in 2004. The ranking then declined in each of the next 3 years and again increased in subsequent years as e-government continued to develop in China (Fig. 7).

The e-government ranking for Pakistan is lower than that of China and has declined over the years (Fig. 8). Pakistan's EDGI improved from 137 in 2003 to

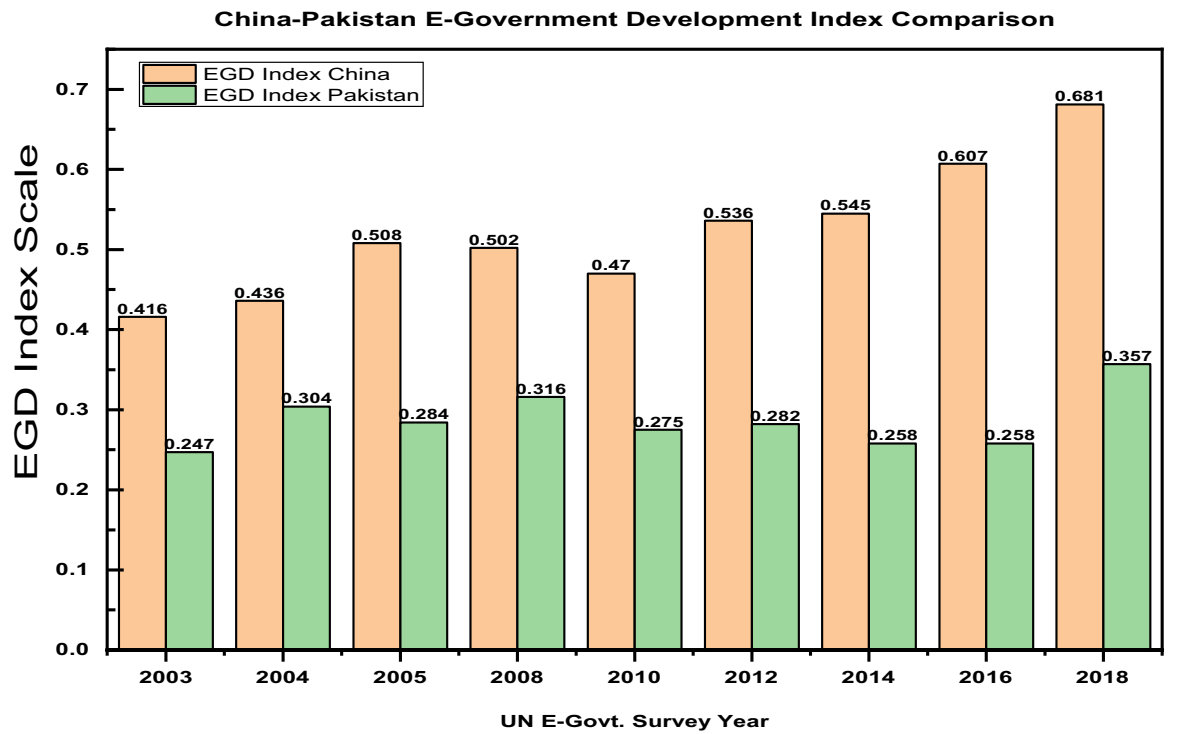

Fig. 8 Comparison of the E-Government Development Index (EGDI) for China and Pakistan 
122 in 2004, but then steadily decreased. In 2008, Pakistan's ranking was 148 out of 193 countries; its EDGI was lower than India's and Bangladesh's EDGI. There were overall positive changes in the EDGI for China and Pakistan except for a few years. In general, Pakistan has a less developed e-governance compared with China.

Based on the EGDI components (Figs. 9, 10, 11) and EPI (Fig. 12), Pakistan needs to adapt and implement a better e-government model in terms of management, facilitation, and participation. The new system needs to provide better online services, human development, and telecommunication infrastructure to improve the country and facilitate e-governance.

Comparison of China's and Pakistan's socioeconomic key indicators demonstrates the country's overall sustainability and development determinants also fluctuate with time (Fig. 13). The graphical comparison between the two countries in terms of EGDI, HDI, real GDP growth, gross national savings, valueadded services, ICT exports, and the Globalization Index (composite of the social, economic, and political indices) also shows that with the help of efficient and effective implementation of active government policies, e-governance in China has improved. At the same time, Pakistan's socioeconomic indicator performance indicates that the government needs to markedly improve to achieve sustainable development. The CPEC project objective is to bring sustainable development in the region and to serve the interests of both countries in the future. The impact of the COVID-19 pandemic on sustainable growth and development is vast. Economies are shrinking, and at this time of crisis, CPEC is the most important project to provide employment opportunities and to bring development and growth in the region.

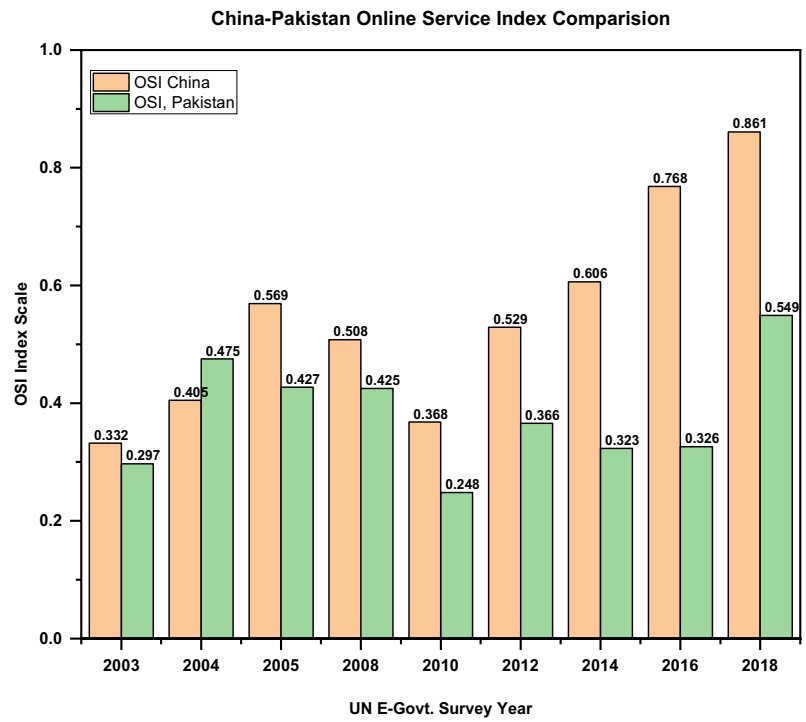

Fig. 9 Comparison of the Online Service Index (OSI) for China and Pakistan (data source: UN.org) 


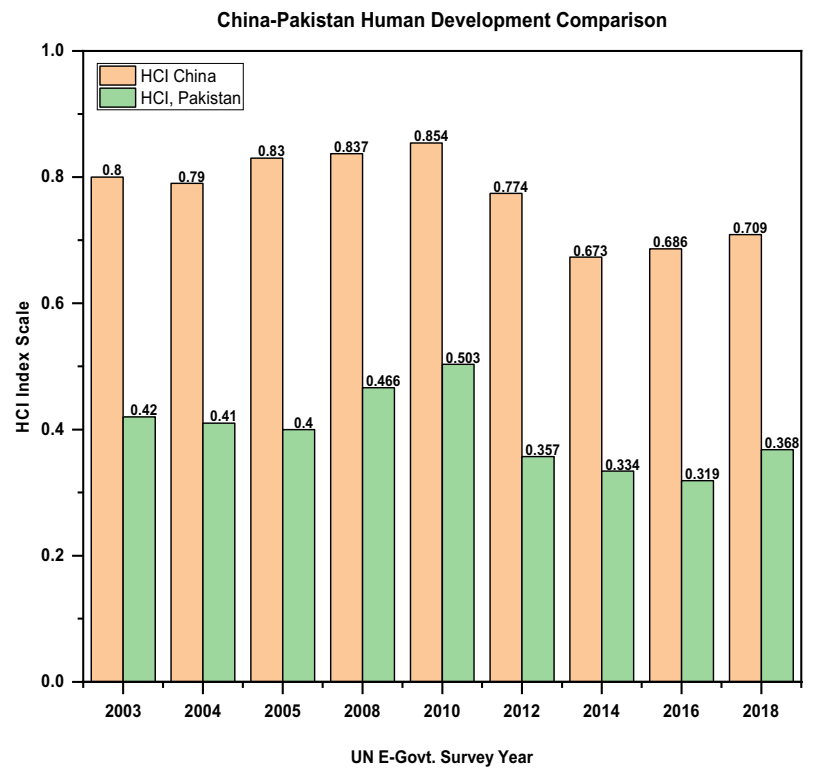

Fig. 10 Comparison of the Human Capital Index (HCI) for China and Pakistan (data source: UN.org)

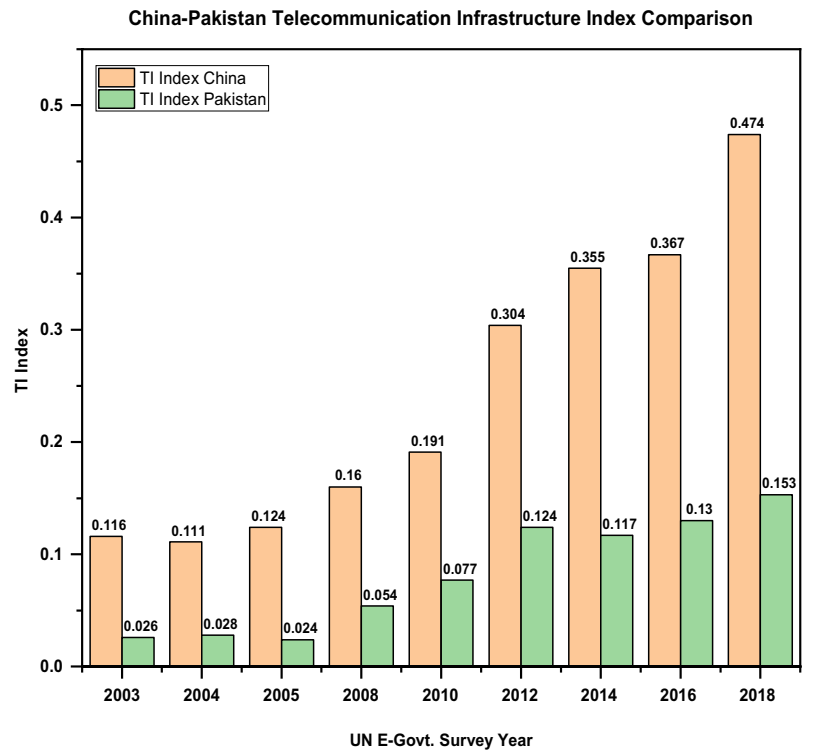

Fig. 11 Comparison of the Telecommunication Infrastructure Index (TII) for China and Pakistan (data source: UN.org) 


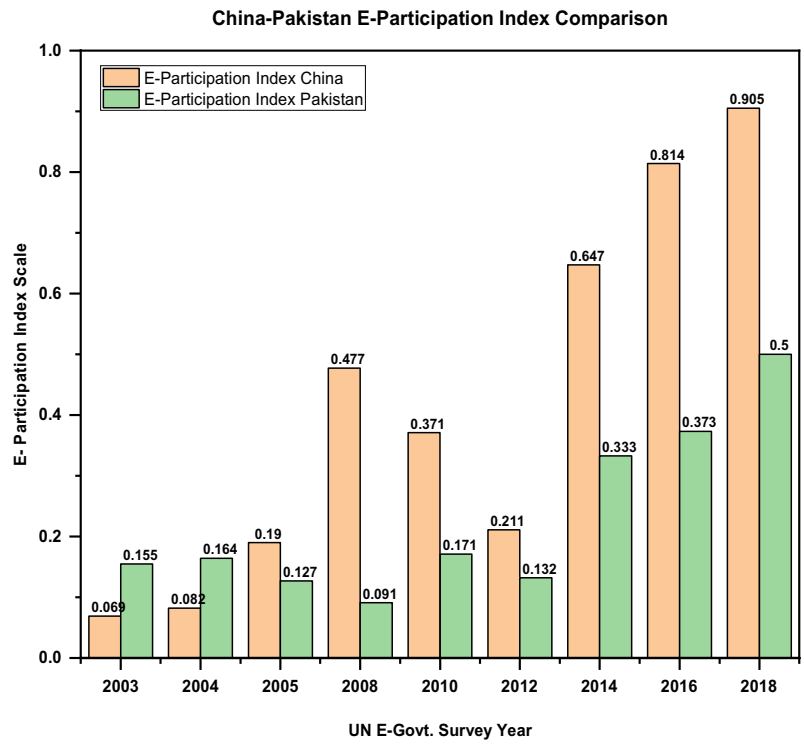

Fig. 12 Comparison of the E-Participation Index (EPI) for China and Pakistan (data source: UN.org)।

\subsection{China E-Governance Enhancement and Combating the COVID-19 Pandemic Experience}

Electronic or digital health is part of citizen services provided by e-government (Alguliyev and Yusifov 2017). The Chinese government policies and overall statistics show that the government is aware of e-government value and is working on its development. Hence, they should continue to develop e-government to ensure continued economic success, especially with how it has successfully facilitated combating the COVID-19 pandemic. In addition, administrative services should preferably use ICT rather than physical systems to further promote development. During the COVID-19 pandemic, the Government of China has shown efficient use and demonstrated how to successfully implement e-government activities at the government, citizen, and business levels to combat and mitigate the effects of COVID-19 (MIIT 2020). The highlights of China's technology use during COVID-19 are described below.

Coping with the rapid spread of COVID-19 requires effective coordination between government authorities, hospitals, and patients to provide prompt clinical care. The National Telemedicine Center of China established the Emergency Telemedicine Consultation System to respond rapidly to this crisis; this system has enabled a response network and outbreak alerts. This system reduces the risk of exposure to respiratory secretions by facilitating the avoidance of physical contact and preventing nurses and physicians from potentially becoming infected (Zhai et al. 2020).

The Shanghai provincial government and Center for Disease Control, along with the Fudan University's artificial intelligence applications, developed a unique 

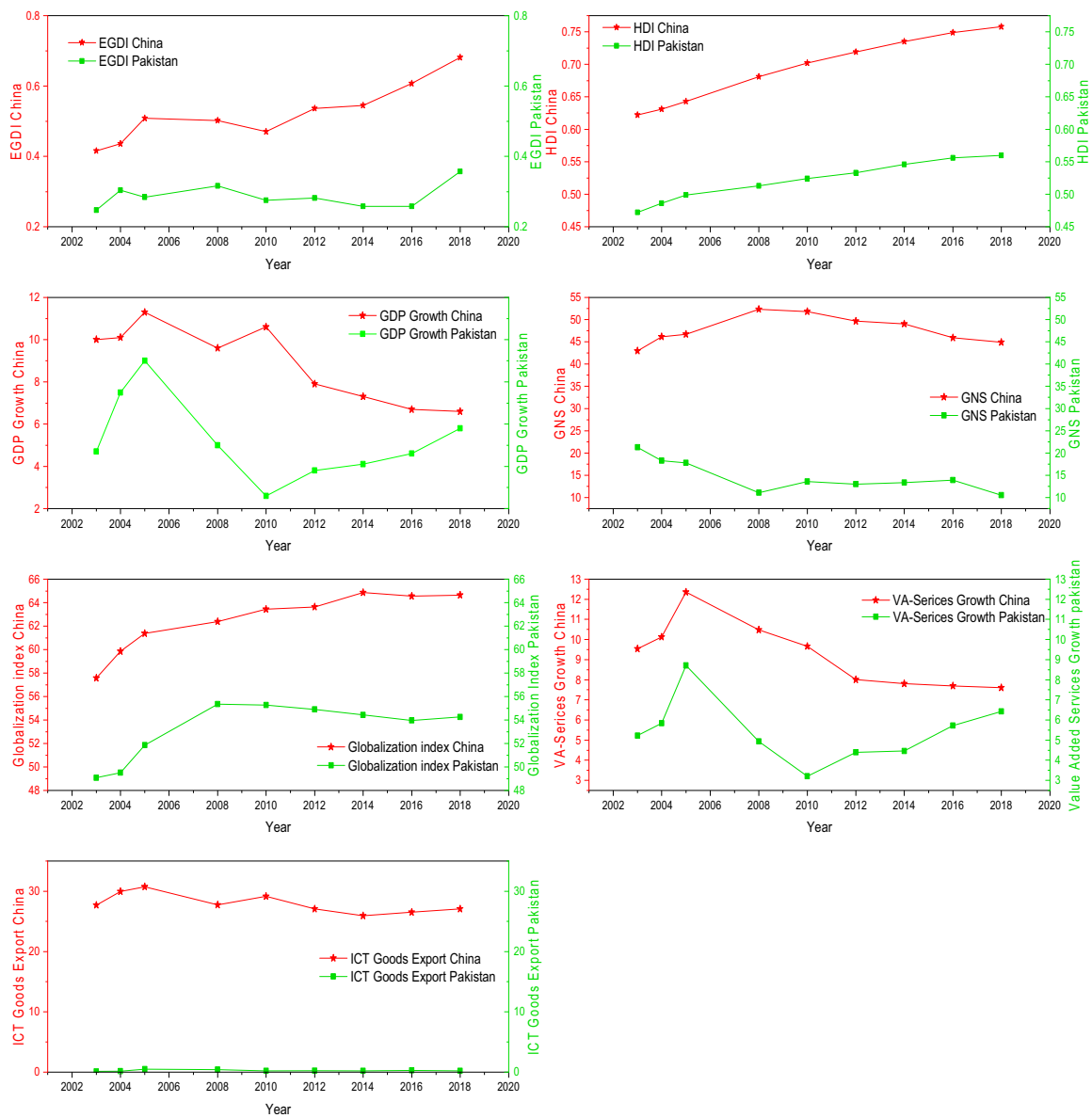

Fig. 13 Comparison of socioeconomic key indicators of China and Pakistan (data source: UN.org for the EGDI, World Bank for other indicators)

medical screening and respiratory blockage checkup system, which augmented the decision-making speed of the scan system. The system performed a quick respiratory scan on more than $93 \%$ of Shanghai citizens (JingjiCCTV 2020). Baidu big data (BBD) was used to identify clusters of infected people. During the early stage of COVID-19 spread, people's movement from one place to another was identified through their mobility data. This endeavor informed critical decisions on lockdown in certain high-risk zones. Furthermore, employing BBD eased the recovery process to discover potential future risk zones when factories or shops would reopen (BBD 2020; CAC 2020; Hua and Shaw 2020).

The Chinese Ministry of Transport (MOT) issued a circular on February 14, 2020 to use advanced technologies to combat the risks of COVID-19 and develop recovery policies (MOT 2020). The government made extensive use of $5 \mathrm{G}$ networks and other technologies, mainly with regard to transportation to detect a vehicle's 
mobility and their related information such as driver, plate number, and other identifying features. Both $5 \mathrm{G}$ and drones were employed in the system of transportation to detect whether laws had been violated during the emergency. In Guangdong, police and public officials' helmets had thermal cameras to provide quick thermal scans; these data were then sent to the appropriate entities using the 5G network. During peak COVID-19 spread in Wuhan, both 5G and robotics were employed to sanitize the city and control disease spread control, especially because public facilities potential hotspots were infections could occur. Likewise, in some high-risk regions, goods were delivered via automated vehicles equipped with 5G technology. Moreover, telemedical care were also run by using $5 \mathrm{G}$ and played a large role in the newly constructed Wuhan hospital (JingjiCCTV 2020).

Chen (2020) argued the positive and negative consequences of the system on the grounds that tools like surveillance and epidemic maps need to be combined with a view of how people react under pressure. Hua and Shaw (2020), Chen (2020), and Xinhuanet (2020) described that to detect infected people, the government developed a unique health barcode system. A user creates a health barcode by signing up for the "close contact detector app" by registering their name, ID, and phone number and then scanning a QR code with smartphones. This app tells the user how far they are from someone who is infected. This barcode system has a three-color coding scheme in which red indicates infected people, yellow indicates caution required, and green indicates good health. Using this information, people can decide which public transport to take and which buildings to enter. Online maps of the locations of infected people could be made with the health barcode, and people could avoid clusters of infected people. If a user had had close contact with a COVID19-diagnosed patient, then the app sends an alert to health officials and also recommends self-quarantine. Furthermore, to develop the health barcode, Baidu's location (GPS) data were combined with big data. This system was first used on February 11, 2020, in the city of Hangzhou. From February 18, this system was also employed in Wuhan, and from March 10, it was used in all of Hubei province. It was progressively employed in 200 other Chinese cities.

Technological and economic growth/stability aspects are vital for the sustainable development of society and to respond and combat effectively to an emergency like the COVID-19 pandemic. WeChat Pay is widely used in China; it also provides personal chats; calls; online air, train, and cinema bookings; and many more services with cell phones grounded on the WeChat app. To complete a transaction, WeChat only needs to link a debit card to WeChat payment. Another widely mode of online transactions in China is AliPay. The WeChat Wallet includes a number of payment methods, including AliPay. With this method, the seller completes a transaction by scanning the QR code that is on AliPay page that purchasers show. Vendors generate different QR codes for each product. When the code is scanned by the user, purchasers can see the information about the product and are guided through the transaction on their cell phones. Through the Web-based payment app, the followers received messages from vendors through their authorized accounts about the products.

Furthermore, followers can buy goods from shopping sites use WeChat Pay. The app payment system sellers may combine the software development kit and WeChat Pay within their apps. Even if users make their payments in another app, WeChat 
will be able to proceed with their payments. Moreover, when the transaction is complete, the page will redirect to the specific app. It has been the most adopted way of buying during lockdown because it supports living in the strict lockdown in Hubei province.

According to Heggestuen (2014), AliPay overhauled PayPal as the world's most used cell phone payment system in 2013. More than $5 \%$ of the world population uses this payment system, and up to now, it has more than 270 million user accounts. More than 1.97 million payment transactions have been done on cell phones, as reported by the Alibaba website. Ant Financial, a financial technology company, operates AliPay. AliPay is used to pay for online purchases of goods and services, but currently it is more than that. A "super app" has become a global lifestyle-for example, tracking and controlling payments made from government treasuries, so many states have employed and combine with financial management systems. Of note, the Karnataka state by satellite-based net connects all 215 treasuries. Now each payment is mainly authenticated to ensure that all payments exist within the budget. These arrangements help to control disbursement while not fully manipulating the system to tackle corruption and upgrade facility conveyance. Implementing management software solutions is challenging because they are complex and must be broad in their scope to provide actual advantages such as consistency and endto-end control of their operation in the implementation of the better electronic system. One green solution is to provide paperless COVID-19 test results to control the expenditures while still effectively combatting COVID-19 spread.

Technological advancement and strong bilateral relationships like the BRI should enhance e-governance setup in China and other counties. China's e-governance has significantly improved by managing the world's largest population (around 20\% of the world population) and efficiently providing them e-services. In late 2019 and early 2020, the Government of China, with the collaboration of private technology firms, has launched 5G technology to make its services more efficient. This advancement has helped to combat the COVID-19 pandemic. China has put all its resources into action to ensure their e-services are easily accessible during the Wuhan lockdown situation, i.e., online grocery shopping, online vegetable trading, and daily situational analysis for its citizens. Moreover, China has launched a study partner application for local and international students that provides updates on preventive measures, government action plans, and situation analysis of the COVID-19 pandemic. This prototype period should make them more competent for when implementing future e-governance services.

\subsection{Discussion on Pakistan E-Governance Enhancement, CPEC, and Combating the COVID-19 Pandemic}

Pakistan has also been improving its e-governance development since 2018, although compared with China, this process has not been as effective (per UN report 2018 and GOP 2017 report). In 2018, the newly sworn-in Government of Pakistan made some positive e-government initiatives. On October 28, 2018, the Prime Minister launched a complaint website (www.pmo.gov.pk/) at the state and provincial 
level as well as for overseas Pakistanis to make e-governance services better and more transparent, with one-window operations in ease of doing business (PMO 2020). In addition, visa, passport, and national identity card services (www.nadra .gov.pk) became available online, all of which are good initiatives and ways to promote e-governance and socioeconomic development by providing easier access to public services.

The National Health Services plan in (2020) launched an initiative to combat the COVID-19 pandemic. For information and complaints, call services on 1166 has been launched (https://covid.gov.pk/). A COVID-19-designated website has been launched for the public; it provides updated situation analysis and raises awareness toward preventive measures against COVID-19. Moreover, regular mobile SMS messages have been sent to the public as public services messages and develop awareness about this situation. The Government of Pakistan, in collaboration with provincial and institutional stakeholders, released a National Action to ensure a timely, effective, and efficient response to the COVID-19 pandemic on February 12, 2020. The plan aimed to control the spread of the virus and to strengthen country and community emergency responses (PIDE News Letters 2020). The Government of Pakistan has taken several steps to combat COVID-19, such as designating hospitals for infected patients, establishing quarantine centers and testing facilities, implementing treatments, increasing public awareness, and facilitating local community responses against the COVID-19 outbreak.

Chinese practices have shown socioeconomic growth and poverty alleviation; for example, the government has successfully controlled COVID-19 and lifted about 700 million people out of poverty in the past 30 years (Weiping 2018). During the lockdown, the strategies from China and Pakistan have been quite different. China imposed a complete lockdown in Wuhan, which is the epicenter of the COVID-19 outbreak, whereas Pakistan imposed a smart lockdown; after two months, Pakistan removed the lockdown due to its weak economic conditions. China is one of the largest manufacturers of protective equipment, and China used the concept of e-governance to provide protective equipment across the country. China is providing room for expertise development through medical support, vocational and technical centers to modulate unemployment, and poverty alleviation impacts from the COVID-19 pandemic.

China and Pakistan are collaborating to combat the COVID-19 pandemic. China has provided medical equipment, ventilators, masks, testing kits, and many more high-priority items for doctors and the public in Pakistan to identify and treat patients. Chinese medical staff and doctors came to Pakistan to guide Pakistani doctors and medical staff (Latif 2020). Moreover, under CPEC, China can help alleviate the current COVID-19 pandemic situation and economic shortfall by dealing with trade obstacles and resistances, involving tariff and non-tariff barriers, to form an environment suitable for entrepreneurs to furnish and boost the import and exportable products. China has also provided assistance to Pakistan to counter this crisis. In addition, Chinese technology companies have cooperated with the Government of Pakistan to improve their e-government. China has shared models, designs, and technology with Pakistan to manufacture testing kits and KN95 masks, and now Pakistan has started to manufacture these items. These efforts will show positive 
impacts on the incoming UN reports and indices. Hence, CPEC has improved trade, markets, regional practices, and socioeconomic factors in Pakistan, especially during and after the COVID-19 pandemic. However, more work is needed to implement efficiently the appropriate systems.

Many developing countries have inefficient resources and systems, i.e., emergency response, payment and tax collection, etc., which leave the government strapped for cash. In addition, they are unable to impose tax payments, transparent systems and response back in emergencies especially like COVID-19 pandemic. Furthermore, the government takes in less tax revenue due to corruption in the collection process, and the public also has less confidence in the system. In many countries, modernizing e-government systems to respond effectively in emergencies, i.e., the COVID-19 pandemic, is a priority. However, governments aim to increase transparency to build public trust by decreasing corruption, increasing online tax filing, and improving processing system. Modernizing a country's tax system is one of the essential things in developing countries. Lifting a country out of poverty and distributing the resources fairly and transparently requires a modern, effective tax system, which most developing countries lack. Modernization involves identifying potential taxpayers (individuals and enterprises) to determine their income such as Pakistan, India, and Bangladesh (Nurunnabi 2020; Shkarlet et al 2020). Given the above-mentioned issues, studying the role of e-governance for combating COVID19 to promote sustainable socioeconomic development is essential. In developing countries like Pakistan, this endeavor is not easy to implement without an efficient model like China.

\section{Conclusions and Policy Inferences}

We investigated the role of e-governance in combating the COVID-19 pandemic impact and promote the sustainability of CPEC. We evaluated the role of e-governance in combating COVID-19 in China and Pakistan by analyzing several indices: EGDI, including OSI, TTI, and HCI; the E-Participation Index; online services; and economic and social measures. China's EGDI ranking has improved from 74 to 65 out of 193 countries, while Pakistan's ranking has gradually declined from 137 to 148, except for 2008. Internet usage has increased in China and Pakistan during the COVID-19 pandemic. Therefore, Internet technology performance and e-governance enhancement during the COVID-19 pandemic have helped to combat COVID19-related impacts.

We also analyzed WHO data on COVID-19 number of total patients, total deaths, daily new confirmed cases, and daily deaths until June 18, 2020. By that date, Pakistan had twice as many cases compared with China. In China, the pandemic peaked in February, and the curve flattened by the end of May. The first cases in Pakistan were confirmed on February 27, 2020, but from the beginning of April when the government implemented a strict lockdown. The number of cases markedly increased. The situation in Pakistan appears to be getting worse. Moreover, based on daily deaths, China has controlled the patient death ratio, while in Pakistan, this measure is still increasing. The graphical comparison between the two countries in 
terms of real GDP growth, gross national savings, value-added services, ICT, and exchange rate index also shows that with the help of efficient and effective implementation of the government system, e-governance policies, China has improved. In sustainable socioeconomic development, Pakistan needs significant improvement. We conclude that Pakistan can adapt and learn from China and other successful e-governance models to integrate CPEC, to combat the COVID-19 pandemic, and to achieve sustainable development. E-Governance is noteworthy because it enhances government control, directly involves citizens, provides high transparency, minimizes corruption, increases convenience, and leads to GDP growth. Moreover, under the BRI, CPEC can help the entire region combat the COVID-19 pandemic. Under CPEC projects, both countries are working together to seek out social and economic problems and get more out of this technology advancement. Thus, e-governance is particularly relevant for CPEC.

In the era of increased need and IT expansion, reformulating the National Digital Pakistan Policy has become imperative. It should facilitate progressive transformation throughout all sectors to ensure social and economic growth, hasten digitization, and ultimately lead to a knowledge-based economy. The Digital Pakistan Policy (2017) should (1) reduce regional digital disparities by exploiting the quickly escalating telecom network, (2) transform the procurement and payment systems to make them efficient by growing financial inclusion through advanced channels, and (3) increase access to education and health facilities in underprivileged and remote zones using the Internet.

In Pakistan, cell phone diffusion and broadband contributions are rising. Considering the increased worth of emerging financial technology firms, software developers, and cellular operators, the digital policy of the Government of Pakistan is being revamped. Pakistan's e-governance should not just be concerned with providing access to documentation, but it should also facilitate digital money transactions and utilization at government and public level like in China. China has efficiently used AliPay and WeChat, and software, telecom, and financial technology companies have the vision to employ their efforts to add value in the economy through e-commerce, e-health, e-agriculture, e-energy, and e-governance. The Government of Pakistan should revamp and implement value-added digital policy characteristics such as for better e-governance, the ability to combat COVID-19 and other future diseases, and to promote sustainable development. This endeavor includes several factors. (1) The government should envision creating databases from ministries and commissions that are compatible with one other. In addition, cloud computing facilities could be introduced to make centralized information more reachable and safer through "G-cloud" servers. A digital mechanism can be used in the public sector to procure goods and services. (2) A dedicated online information portal should be constructed to improve e-agriculture like the China agricultural system framework, which provides farming and livestock communities with information about modern and innovative production methodologies. In addition, to improve monitoring and encourage sustainable cultivation, software creators are being appointed to revamp Geographical Information Systems. Finally, to make this transition smoother, financial technology firms can develop digital modes of procurement and marketing through the Internet, and some facilities will be delivered to the growers such as 
regional language support and IT skills development training. (3) Better electronic health systems are required to enhance the satisfactory approach of health, and, after the COVID-19 pandemic, one of the primary objectives of the health policy of any country should be to provide facilities and combat COVID-19 and future diseases. For that matter, distant advisory facilities, particularly in rural areas, should be initiated through the Internet and combined with a mobile health app to integrate and centralize patient records. Furthermore, there should be a collaboration of mobile wallet providers to provide digital payment options like AliPay and WeChat in China. (4) For a better e-commerce system and effective economic growth, the Government of Pakistan should have responsibilities on all fronts, including financial awareness and inclusions, digital interoperability of payment system providers, and formation of a centralized payment gateway system to accomplish the objective of triple the e-commerce market.

By adopting China's e-governance model, the Government of Pakistan will be able to coordinate and maximize reusability, support standardization efforts, create synergies, and provide cost-effectiveness through involving international standardized facilitation as well as support in effectively combating COVID-19. Incorporating the e-governance system in public schools can have a meaningful impact on the current education ecosystem during COVID-19 and can ensure sustainable socioeconomic development. Sustainable development can be provided in a phased manner because, as per the report of State Bank of Pakistan (2018), there is no official data available about the proportion of Pakistani schools that have access to broadband Internet. Universal connectivity can lower the barrier to education because the majority of public schools are concentrated in rural areas; utilizing e-education platforms can enhance quality and access and help to execute the UN's SDG for quality education. CEPC should allow collaboration with China and international partners to boost ICT innovation, a necessary endeavor for this rapidly growing technology era to generate entrepreneurship, sustain innovation, combat COVID-19 and future diseases, and provide employment. New opportunities for entrepreneurial youth who will develop ICT will improve Pakistan's ranking based on international indicators and benchmarks that measure the infrastructure, business and innovation environment, skills readiness, affordability, and social and economic effects. Better e-governance can boost the domestic market, software exports, and IT remittances. Federal and provincial capitals are substantial to promote e-governance; they need at least one state of the art "technology park" or IT economic zone under CPEC as soon as possible. Better e-governance systems can increase domestic and foreign investment, and with this investment, Pakistan can combat with COVID-19 impact and can promote an attractive terminus for investment within IT/ITES businesses to generate jobs and stimulate sustainable economic development. A better e-governance system in Pakistan can facilitate digital inclusion by bridging the digital divide between rural and urban areas, namely to link these areas with reliable broadband Internet access. A future study can highlight how financial technology can provide solutions to health crises such as the COVID-19 pandemic.

Acknowledgements We are very grateful to Mr. Asif Ali Safeer and Mubasher Zaman for their helpful comments and suggestions which improved the draft. 
Author contributions AU: his research interests include sustainable development, poverty alleviation, regional integration, belt and road countries, e-governance, topics in finance and economics i.e., monetary policy, financial stability, corporate governance, risk management, investments, and currency depreciation. CP: currently, he is also business consultant at Xiamen Jinlong United Automobile Industry Co., Ltd., China Poverty Alleviation and Development Center, Wuhan Local Taxation Bureau, Shandong Huaguan Wine Group, Hubei Guobao Qiaomi Co., Ltd., etc. Moreover, he is a former GloColl Program holder, Harvard Business School, USA. Besides that, he is former National Public Visiting Scholar, Andrew Young School of Public Policy, Georgia State University and Visiting Scholar of the School of Finance of Prague University of Economics. Research interests include public economic theory and government performance evaluation, macroeconomics, risk management, corporate strategy and decision-making, poverty alleviation, etc. Official profile: https://cm.hust.edu.cn/info/1754/24502.htm. SU: research interests include sustainable development, regional integration, topics in finance and economics, i.e., financial stability, corporate governance, risk management, efficiency, behavioral finance and sustainability. HSMA: research interests include public services, governance, globalization, public management, public administration and sustainable development. SK: research interests include e-government, sustainable development, services management, entrepreneurship, and microfinance.

Funding This work was supported by the Huazhong University of Science and Technology, Wuhan, China [Project Name: National Natural Science Foundation of China (No: 71703047).

\section{Compliance with ethical standards}

Conflict of interest The authors reported no potential conflict of interest.

\section{References}

Akber, M.Z., M.J. Thaheem, and H. Arshad. 2017. Life cycle sustainability assessment of electricity generation in Pakistan: policy regime for a sustainable energy mix. Energy Policy 111: 111-126. https:// doi.org/10.1016/j.enpol.2017.09.022.

Albesher, A. 2016. Trust as a source of long-term adoption of e-government (doctoral thesis). Uxbridge, United Kingdom: Brunel University London.

Alguliyev, R., and F. Yusifov. 2017. Electronic health as a component of G2C services. IJACSA 8 (3): 201-206.

Ali, F.H., and A.A. Qazi. 2018. Exploring the awareness of China Pakistan economic corridor: a stakeholder's perspective. South Asian Studies 33 (1): 107-116.

Ali, M.A., M.R. Hoque, and K. Alam. 2018. An empirical investigation of the relationship between e-government development and the digital economy: the case of Asian countries. Journal of Knowledge Management. https://doi.org/10.1108/JKM-10-2017-0477.

Alshehri, M., and Drew, S. 2010. E-government fundamentals. In IADIS international conference ICT, society and human beings 2010. Retrieved 18 June 2020 from https://hdl.handle.net/10072/37709.

Alwashmi, M.F. 2020. The use of digital health in the detection and management of COVID-19. International Journal of Environmental Research and Public Health 17 (8): 2906. https://doi.org/10.3390/ ijerph17082906.

Andersen, K.N., J.A. Nielsen, and S. Kim. 2019. Use, cost, and digital divide in online public health care: lessons from Denmark. Transforming Government: People, Process and Policy.

Aiva Health. 2020. Virtual Health Assistant. Available online: https://aivahealth.com/ (accessed on March 30 2020).

BBD. 2020. Baidu Big Data: available from, accessed on March 292020.

Buoy health. 2020. Symptom checker, check your symptoms in real-time. Buoyhealth.com. Published in 2020. Retrieved 18 June 2020, Available online: https:/www.buoyhealth.com/symptom-checker/.

Butt, N., N.F. Warraich, and M. Tahira. 2019. The development level of electronic government services. Global Knowledge, Memory and Communication. https://doi.org/10.1108/GKMC-05-2018-0045.

CAC. 2020. Cyberspace Administration of China: Retrieved 18 June 2020 from https://www.cac.gov.cn/. 
Chen, A. 2020. China's coronavirus app could have unintended consequences. MIT Technology Review. https://www.technologyreview.com/s/615199/coronavirus-china-app-close-contact-surve illance-COVID-19-technology/. Accessed 13 Feb 2020.

COVID-19 live dashboard (Pakistan). 2020. National Institute of Health Islamabad, Retrieved 18 June 2020 from https://www.nih.org.pk/novel-coranavirus-2019-ncov/.

Ookla. 2020. China internet performance during COVID December 2019 to June 15, 2020, Source: Speedtest, Ookla, Retrieved 18 June 2020 from https://www.speedtest.net/insights/blog/trackingCOVID-19-impact-global-internet-performance/\#/China.

De Ceukelaire, W., and C. Bodini. 2020. We need strong public health care to contain the global corona pandemic. International Journal of Health Services. https://doi.org/10.1177/0020731420916725.

DeloitteASSIST. 2020. Deloitte New Zealand. Available online: https://www2.deloitte.com/nz/en/ pages/ life-sciences-and-healthcare/articles/deloitte-assist.html (accessed on 30 March 2020).

Dresel, R., M. Henkel, K. Scheibe, F. Zimmer, and W.G. Stock. 2020. A nationwide library system and its place in knowledge society and smart nation: the case of Singapore. Libri 70 (1): 81-94.

Digital Pakistan Policy, 2017. Retrieved 18 June 2020 from https://propakistani.pk/2017/08/15/digitalpakistan-policy-2017-glance/.

Faid, G., M.M. Tariq, A. Ishtiaq, V.L. Zeynvand, D.F. Meyer, and D. Máté. 2020. The nexus of E-government and increased productivity relative to income level comparison. Business, Management and Education 18 (1): 88-105. https://doi.org/10.3846/bme.2020.12067.

Farooqui, M.A., and S.M. Aftab. 2018. China-Pakistan economic corridor; prospects and challenges for Balochistan, Pakistan. IOP Conference Series Materials Science and Engineering 414 (1): 012046. https://doi.org/10.1088/1757-899X/414/1/012046.

Gao, X., and J. Yu. 2020. Public governance mechanism in the prevention and control of the COVID-19: information, decision-making and execution. Journal of Chinese Governance 5 (2): 178-197. https ://doi.org/10.1080/23812346.2020.1744922.

GOP. 2017. People to people exchanges. https://cpec.gov.pk/project-details/61. Accessed 31 Oct 2020.

GOVTECH. 2020. Trace together-behind the scenes look at its development process. Singapore. Published in 2020. Retrieved 18 June 2020, Available online: https://www.tech.gov.sg/media/technews/ tracetogether-behind-the-scenes-lookatits-development-process.

Gustova, D. 2017. The impact of e-government strategy on economic growth and social development (Doctoral dissertation).

Haider, S.F. 2015. The game-changer. The express tribune. Accessed 14 May 2015. https://tribune.com. $\mathrm{pk} /$ story/885778/the-game-changer-2/>

Haider, M. and I. Haider. 2015. Economic corridor in focus as Pakistan. China sign 51 MoUs. Retrieved from https:/www.dawn.com/news/1177109/economic-corridor-in-focus-as-pakistan-china-sign-51mous. Accessed 11 Dec 2015.

Haque, N. U. and Nayab, D. E. 2020. PIDE COVID-19 E-BOOK. Pakistan Development Review, Retrieved 18 June 2020 fromhttps://www.pide.org.pk/pdf/PIDE-COVID19-EBook.pdf.

Healy, E., and J. Casey. 2013. Driving sustainability, the Cfo's role report. Finance Leadership Accountancy IRELAND 45: 6.

Heggestuen, J. 2014. Alipay overtakes PayPal as the largest mobile payments platform in the world. Business Insider, February, 11. Retrieved 18 June 2020 from https:/www.businessinsider.com/alipa y-overtakes-paypal-as-the-largest-mobile-payments-platform-in-the-world-2014-2.

Hiss, S. 2013. The politics of the financialisation of sustainability. Competition and Change 17 (3): $234-$ 247. https://doi.org/10.1179/1024529413Z.00000000035.

Hou, E. 2014. Government WeChat, expired" old ticket"-disregard the changing circumstances, how far could the new deal? China Media Report Overseas 10 (1): 1-8. https://doi.org/10.3390/fi9030053.

Hua, J., and R. Shaw. 2020. Coronavirus (COVID-19) "infodemic" and emerging issues through a data lens: the case of China. International journal of environmental research and public health 17 (7): 2309. https://doi.org/10.3390/ijerph17072309.

Hussain, E. 2017. China-Pakistan economic corridor: will it sustain itself? Fudan Journal of the Humanities and Social Sciences 10 (2): 145-159. https://doi.org/10.1007/s40647-016-0143-X.

JingjiCCTV. 2020. Retrieved 18 June 2020 from https://jingji.cctv.com/.

Kaimuri, B., and G. Kosimbei. 2017. Determinants of sustainable development in Kenya. Journal of economics and sustainable development 8: 17-36.

Khan, M., Khurram, DS and Zubair, DSS. 2020. Societal e-readiness for e-governance adaptability in Pakistan. Pakistan Journal of Commerce and Social Sciences, 14:1 273-299. Retrieved from https:// hdl.handle.net/10419/216872. Accessed 18 June 2020. 
Koirala, B.S., and G. Pradhan. 2020. Determinants of sustainable development: evidence from 12 Asian countries. Sustainable Development 28 (1): 39-45. https://doi.org/10.1002/sd.1963.

Latif, A. 2020. Chinese doctors to join Pakistan's COVID-19 battle, Anadolu Agency website. https ://www.aa.com.tr/en/asia-pacific/chinese-doctors-to-join-pakistans-covid-19-battle/1817676. Assesed 24 Apr 2020.

Lu, W. 2018. The Research of E-government on Big Data in China. In 2018 International Conference on Management, Economics, Education, Arts and Humanities (MEEAH 2018). 40-43. Atlantis Press. Retrieved 18 June 2020 from https://creativecommons.org/licenses/by-nc/4.0/.

Lark Health. 2020. Digital disease management and prevention platform. Published in 2020. Retrieved 18 June 2020, Available online: https://lark.com/.

Ma, Y. 2019. Study on the risk and analyse the preventive measures of we-chat pay. The International Conference on Cyber Security Intelligence and Analytics, 1195-1199. Cham: Springer.

Mangi, F., and Haider, K. 2014. Pakistan's Sharif Seeks Energy Deals during China Visit. Bloomberg Business, November 6.

Mazher, S., Khan, M.F., Ali, M.S. Aliani, F. Amin, MA and Daulat, A. 2015. CPEC: A big impetus for growth and investment, Economics Pakistan. Retrieved 18 June 2020 from https://www. scribd.com/document/353259091/Pakistan-Strategy-CPEC-a-Big-Impetus-for-Growth-and-Inves tment.

Menhas, R., S. Mahmood, P. Tanchangya, M.N. Safdar, and S. Hussain. 2019. Sustainable development under belt and road initiative: a case study of China-Pakistan economic corridor's socioeconomic impact on Pakistan. Sustainability 11 (21): 6143. https://doi.org/10.3390/su11216143.

MIIT. 2020. Ministry of Industry and Information Technology of the People's Republic of China. Retrieved 18 June 2020 from https://www.miit.gov.cn.

Moberly, J.G., M.T. Bernards, and K.V. Waynant. 2018. Key features and updates for origin 2018. Journal of Cheminformatics 10 (1): 5. https://doi.org/10.1186/s13321-018-0259-x.

MoHW. 2020a. Self-diagnosis mobile app instructions. Retrieved 1 June 2020 from https://ncov. mohw.go.kr/selfcheck.

MoIS. 2020. Self-quarantine Safety Protection App. Available from https://www.mois.go.kr. Accessed 28 Mar 2020.

MOT. 2020. Ministry of Transport of the People's Republic of China, Retrieved 18 June 2020 from https://www.mot.gov.cn.

Nurunnabi, M. 2020. Revisiting accountability: corruption in health care in developing countries. In Integrity, Transparency and Corruption in Healthcare \& Research on Health, Volume I 65-78 Springer, Singapore.

Pakistan National Action Plan. 2020. National Action Plan for Preparedness \& Response to Corona Virus Disease (COVID-19) Pakistan. Retrieved 18 June 2020 from https://www..nih.org.pk/wpcontent/uploads/2020/02/NAP-covid.

Okeleke, K. 2019. The power of mobile to accelerate digital transformation in Pakistan. GSMA Report, Retrieved 18 June 2020 from https://www.gsma.com/mobilefordevelopment/wp-content/ uploads/2019/10/The-Power-of-Mobile-to-Accelerate-Digital-Transformation-in-Pakistan-2019. pdf.

Otioma, C., A.M. Madureira, and J. Martinez. 2019. Spatial analysis of urban digital divide in Kigali Rwanda. GeoJournal 84 (3): 719-741.

Pakistan telecommunication authority. 2019. E-services. Accessed April 8, 2019, Available at https:// www.pta.gov.pk/en.

Phimphanthavong, H. 2014. The determinants of sustainable development in Laos. International Journal of Academic Research in Management (IJARM) 3 (1): 2296-1747 (ISSN).

PIDE COVID Newsletter E-Book. 2020. Retrieved 18 June 2020 from https://www.pide.org.pk/pdf/ Newsletter-E-Book.pdf..

Pakistan Internet Performance. 2020. During COVID December 2019 to June 15, 2020, Source: Speedtest, Ookla, Retrieved 18 June 2020 from https://www.speedtest.net/insights/blog/tracking-COVID -19-impact-global-internetperformance/\#/Pakistan.

Pakistan National Human Development Report, 2018. Unleashing the human development indices and indicators: 2018 Statistical update, Potential of a Young Pakistan, Retrieved 18 June 2020 from https ://hdr.undp.org/sites/all/themes/hdr_theme/country-notes/PAK.pdf.

Rafiq, A. 2018. E-governance in Pakistan: A reality check. Issue Brief, Institute of Strategic Studies Islamabad, Retrieved 18 June 2020 fromhttps://issi.org.pk/wpcontent/uploads/2018/02/IB_Aamna _February_27_2018.pdf. 
Rehman, K., Shah, A.A. and Ahmed, K. 2018. E-government identification to accomplish sustainable development goals (UN 2030 Agenda), a case study of Pakistan. In 2018 IEEE Global Humanitarian Technology Conference (GHTC) 1-6 978-1-5386-5566-5/18/\$31.00 @2018 IEEE.

Sarker, M. N. I., Hossin, M. A., Frimpong, A. N. K., and Xiaohua, Y. 2018. Promoting information resource management for e-government through big data approach. In Proceedings of the 2018 International Conference on Information Management \& Management Science 99-104.

Schmitter, P.C. 2019. Defining, explaining and then, exploiting the elusive concept of "Governance." Fudan Journal of the Humanities and Social Sciences 12 (4): 547-567. https://doi.org/10.1007/ s40647-018-0236-9.

State Bank of Pakistan Report. 2018. Retrieved 18 June 2020 and Accessed from https://www.sbp.org.pk/ reports/annual/.

Shaw, R., Y.K. Kim, and J. Hua. 2020. Governance, technology and citizen behaviour in a pandemic: lessons from COVID-19 in East Asia. Progress in Disaster Science. 6: 100090. https://doi. org/10.1016/j.pdisas.2020.100090.

Shkarlet, S., I. Oliychenko, M. Dubyna, M. Ditkovska, and V. Zhovtok. 2020. Comparative analysis of best practices in e-Government implementation and use of this experience by developing countries. Administratie si Management Public 34: 118-136.

Solinthone, P., and T. Rumyantseva. 2016. E-government implementation. MATEC Web of Conferences 79: 01066. https://doi.org/10.1051/matecconf/201679010 (EDP Sciences).

Srivastava, S.K., and P.K. Panigrahi. 2016. The impact of e-government and e-business on economic performance: a comparative study of developing and developed countries. Journal of Contemporary Issues in Business and Government, The 22 (1): 36-50. https://doi.org/10.7790/cibg.v22i1 (ISSN, 1323-6903).

Stančić, H., T. Ivanjko, and A. Garic. 2017. Government to business e-services-accountability and trust. Tidsskriftet Arkiv 8: 1. https://doi.org/10.7577/ta.1958.

Sun, X. 2019. Governance value, growth coalition, and models of community governance. Chinese Political Science Review 4 (1): 52-70. https://doi.org/10.1007/s41111-018-0113-3.

Tambo, E., C. Khayeka-wandabwa, G. Wagithi, Y. Liu, S. Tang, and X. Zhou. 2019. China's belt and road initiative : incorporating public health measures toward global economic growth and shared prosperity. Global Health Journal 3 (2): 46-49. https://doi.org/10.1016/j.glohj.2019.06.003.

The Ministry of National Health Services. 2020. Regulation and Coordination, Retrieved 18 June 2020 from https://covid.gov.pk/facilities/List\%20of\%20Province.

Ud Din, I., M.C. Xue, S. Ali Abdullah, T. Shah, and A. Ilyas. 2017. Role of information and communication technology (ICT) and e-governance in the health sector of Pakistan: a case study of Peshawar. Cogent Social Sciences 3 (1): 1308051. https://doi.org/10.1080/23311886.2017.1308051.

United nations e-government survey, 2018. Gearing e-government to support transformation towards sustainable and resilient societies. Department of Economic and Social Affairs. Retrieved 18 June 2020 from https://www.Publicadministration.un.org ISBN: 978-92-1-123205-9 eISBN: 978-92-1-058156-1.

United Nations Member State, 2018. Retrieved 18 June 2020 from https://visit.un.org/sites/visit.un.org/.../ FS_List_member_states_Feb_2013.p.

Wang, J.J., and Y.A.U. Selina. 2018. Case studies on transport infrastructure projects in belt and road initiative: an actor-network theory perspective. Journal of Transport Geography 71: 213-223. https ://doi.org/10.1016/j.jtrangeo.2018.01.007.

Wang, C., P.W. Horby, F.G. Hayden, and G.F. Gao. 2020. A novel coronavirus outbreak of global health concern. The Lancet 395 (10223): 470-473. https://doi.org/10.1016/S0140-6736(20)30185-9.

Waris, A., A.U. Khan, M. Ali, A. Ali, and A. Baset. 2020. COVID-19 outbreak: current scenario of Pakistan. New Microbes and New Infections. https://doi.org/10.1016/j.nmni.2020.100681.

Weiping, T. 2018. China's approach to reduce poverty: taking targeted measures to lift people out of poverty. International Poverty Reduction Center in China. https://www.un.org/development/desa/dspd/ wpcontent/uploads/sites/22/2018/05/15.pdf.

World Bank. 2015. Financing the post-2015 sustainable development agenda, Retrieved 18 June 2020 from https://openknowledge.worldbank.org/.../WBAnnualReport2015EN.pdf.

Xinhuanet. 2020. China publishes white paper on COVID-19 fight. Retrieved 18 June 2020 from https:// www.xinhuanet.com/english/2020-06/07/c_139121660.htm.

$\mathrm{Xu}$, Y. 2010. Notice of Violation of IEEE Publication Principles: E-Government and Governance in China. In 2010 International Conference on Management and Service Science 1-4 IEEE. 
Yang, Y. 2017. Towards a new digital era: observing local e-government services adoption in a Chinese municipality. Future Internet 9 (3): 53. https://doi.org/10.3390/fi9030053.

Yildiz, M. 2007. E-government research: reviewing the literature, limitations, and ways forward. Government information quarterly 24 (3): 646-665. https://doi.org/10.1016/j.giq.2007.01.002.

Yu, Y., and Y.C. Chang. 2018. The 'one belt one road'initiative and its impact on shipping law in China. Marine Policy 87: 291-294. https://doi.org/10.1016/j.marpol.2017.11.003.

Zaidi, S.A. 2016. Undermining the Pakistan military's hegemony. Economic and Political Weekly 51 (36): 13

Zarocostas, J. 2020. How to fight an infodemic. The Lancet 395 (10225): 676. https://doi.org/10.1016/ S0140-6736(20)30461-X (Available online:www.thelancet.com).

Zhai, Y., Y. Wang, M. Zhang, J.H. Gittell, S. Jiang, B. Chen, F. Cui, X. He, J. Zhao, and X. Wang. 2020. From isolation to coordination: how can telemedicine help combat the COVID-19 outbreak? MedRxiv. https://doi.org/10.1101/2020.02.20.20025957.

\section{Affiliations}

\section{Atta Ullah ${ }^{1}$ (1) Chen Pinglu ${ }^{2} \cdot$ Saif Ullah ${ }^{3}$ (D) Hafiz Syed Mohsin Abbas ${ }^{4}\left({ }^{\circ}\right.$. Saba Khan ${ }^{5}$}

Saif Ullah

saifullah_142@yahoo.com

Hafiz Syed Mohsin Abbas

abbas_hsm@hust.edu.cn

Saba Khan

sabakhangishkori@gmail.com

1 School of Management, Institute of Poverty Reduction and Development, Huazhong University of Science and Technology (HUST), Wuhan, China

2 School of Management, Chair of the Department of Financial Management \& Vice Dean of Institute of Poverty Reduction and Development, Huazhong University of Science and Technology (HUST), Wuhan, China

3 Faculty of Management Sciences, SZABIST, Karachi, Pakistan

4 College of Public Administration, Huazhong University of Science and Technology, Wuhan, China

5 National University of Modern Language, (Multan Campus), Islamabad, Pakistan 